\title{
Anacardic Acids from Cashew Nuts Ameliorate Lung Damage Induced by Exposure to Diesel Exhaust Particles in Mice
}

\author{
Ana Laura Nicoletti Carvalho, ${ }^{1}$ Raquel Annoni, ${ }^{1}$ Larissa Helena Lobo Torres, ${ }^{2}$ \\ Ana Carolina Cardoso Santos Durão, ${ }^{2}$ Ana Lucia Borges Shimada, ${ }^{2}$ \\ Francine Maria Almeida, ${ }^{3}$ Cristina Bichels Hebeda, ${ }^{2}$ \\ Fernanda Degobbi Tenorio Quirino Santos Lopes, ${ }^{3}$ Marisa Dolhnikoff, ${ }^{1,4}$ \\ Milton Arruda Martins, ${ }^{3}$ Luiz Fernando Ferraz Silva, ${ }^{1,4}$ Sandra Helena Poliselli Farsky, \\ Paulo Hilário Nascimento Saldiva, ${ }^{1,4}$ Cornelia M. Ulrich, ${ }^{5}$ Robert W. Owen, \\ Tania Marcourakis, ${ }^{2}$ Maria Teresa Salles Trevisan, ${ }^{6}$ and Thais Mauad,4 \\ ${ }^{1}$ Experimental Atmospheric Pollution Laboratory (LPAE), Department of Pathology, São Paulo Medical School, \\ University of São Paulo, Av. Dr. Arnaldo 455/Room 1155, 01246-903 São Paulo, SP, Brazil \\ ${ }^{2}$ Department of Clinical and Toxicological Analyses, School of Pharmaceutical Sciences, University of São Paulo, \\ Av. Prof. Lineu Prestes 580/13b, 05508-900 São Paulo, SP, Brazil \\ ${ }^{3}$ Experimental Therapeutics Laboratory, Department of Clinical Medicine, São Paulo Medical School, University of São Paulo, \\ Av. Dr. Arnaldo 455/Room 1155, 01246-903 São Paulo, SP, Brazil \\ ${ }^{4}$ National Institute for Integrated Analysis of Environmental Risk (INAIRA), National Council for Scientific and \\ Technological Development, Av. Dr. Arnaldo 455/Room 1220, 01246-903 São Paulo, SP, Brazil \\ ${ }^{5}$ Division of Preventive Oncology, National Center for Tumor Diseases, Im Neuenheimer Feld 460/German Cancer Research Center \\ (DKFZ), Im Neuenheimer Feld 581, Heidelberg, Germany \\ ${ }^{6}$ Department of Organic and Inorganic Chemistry, Federal University of Ceará, Campus 12200, 60451-970 Fortaleza, CE, Brazil
}

Correspondence should be addressed to Ana Laura Nicoletti Carvalho; analauranc@yahoo.com.br

Received 15 November 2012; Accepted 21 January 2013

Academic Editor: Y. Ohta

Copyright (C) 2013 Ana Laura Nicoletti Carvalho et al. This is an open access article distributed under the Creative Commons Attribution License, which permits unrestricted use, distribution, and reproduction in any medium, provided the original work is properly cited.

\begin{abstract}
Anacardic acids from cashew nut shell liquid, a Brazilian natural substance, have antimicrobial and antioxidant activities and modulate immune responses and angiogenesis. As inflammatory lung diseases have been correlated to environmental pollutants exposure and no reports addressing the effects of dietary supplementation with anacardic acids on lung inflammation in vivo have been evidenced, we investigated the effects of supplementation with anacardic acids in a model of diesel exhaust particle- (DEP-) induced lung inflammation. BALB/c mice received an intranasal instillation of $50 \mu \mathrm{g}$ of DEP for 20 days. Ten days prior to DEP instillation, animals were pretreated orally with 50,150 , or $250 \mathrm{mg} / \mathrm{kg}$ of anacardic acids or vehicle (100 $\mu \mathrm{L}$ of cashew nut oil) for 30 days. The biomarkers of inflammatory and antioxidant responses in the alveolar parenchyma, bronchoalveolar lavage fluid (BALF), and pulmonary vessels were investigated. All doses of anacardic acids ameliorated antioxidant enzyme activities and decreased vascular adhesion molecule in vessels. Animals that received $50 \mathrm{mg} / \mathrm{kg}$ of anacardic acids showed decreased levels of neutrophils and tumor necrosis factor in the lungs and BALF, respectively. In summary, we demonstrated that AAs supplementation has a potential protective role on oxidative and inflammatory mechanisms in the lungs.
\end{abstract}

\section{Introduction}

Epidemiological studies have clearly associated ambient particulate matter (PM) concentration with a range of adverse effects on respiratory and cardiovascular health as well as increased morbidity and mortality [1-3].

Diesel engine exhaustion contributes considerably to the air particulate composition in urban regions. In São Paulo, 
for instance, a fleet of 14,900 buses powered by diesel fuel are responsible for the majority of public transportation [4]. In healthy subjects, acute diesel exhaust exposure resulted in neutrophils recruitment, upregulation of the endothelial adhesion molecules P-selectin, and vascular adhesion molecule- (VCAM-1) and interleukin- (IL-8) production in the bronchial mucosa $[2,5,6]$. Subchronic exposure to lower levels of diesel exhaust particles (DEP) $(30 \mu \mathrm{g})$ derived from the São Paulo public transportation system has been shown to induce inflammatory alterations in the nose and lungs of healthy mice [7].

The mechanisms by which DEP induces adverse biologic effects on the respiratory system may be via the production of oxidative stress by the exposed cells [2, 8, 9]. Riedl and Diaz-Sanchez [10] observed that DEP exposure may cause increased oxidative stress directly through the induction of reactive oxygen species (ROS) and indirectly through the resultant enhanced inflammation, which generates additional ROS. Additionally, DEP activates redox-sensitive transcription factors, such as nuclear factor kappa $\mathrm{B}(\mathrm{NF}-\kappa \mathrm{B})$ and activator protein- (AP-1) $[2,10,11]$.

While there clearly need to be efforts worldwide to reduce diesel related air pollution, identifying potential protective substances that reduce the harmful respiratory effects of pollutant-induced oxidative stress has been an important research topic in recent years $[2,10]$. Diet is the only source of antioxidant micronutrients [12], and these micronutrients are thought to be important modulators of immune response [2, 13-15]. Antioxidants can upregulate endogenous antioxidant defenses, such as reduced glutathione (GSH), catalase, and glutathione reductase $[16,17]$.

Due to their wide distribution in fruits and plants, polyphenols are the most abundant antioxidants in the diet. The beneficial health effects of dietary polyphenols have recently come to the attention of nutritionists [18].

Anacardic acids (AAs) are alkyl phenols from the cashew (Anacardium occidentale Linn.), a tropical tree native to the northeast region of Brazil. AAs are abundantly present in many parts of the cashew plant and have received attention as a potential antioxidant substance. Cashew apple, cashew nut (raw and roasted), and cashew nut shell liquid (CNSL) contain a range of different alkyl phenols, including AAs, cardanols, and cardols. Higher amounts of AAs have been detected in CNSL $(353.6 \mathrm{~g} / \mathrm{kg})$ followed by cashew fiber $(6.1 \mathrm{~g} / \mathrm{kg})$, while the lowest $(0.65 \mathrm{~g} / \mathrm{kg})$ amounts were found in roasted cashew nut [19].

AAs were described as the main active agent in CNSL. The presence of a phytyl side chain beside the phenolic ring structure (as in salicylic acid) results in its great antioxidant capacity [19]. Diverse biological activities for the AAs have been described, including antimicrobial activity against methicillin-resistant bacteria [20-22], gastroprotection [23], and inhibition of the activity of several clinically targeted enzymes, such as lipoxygenase $[24,25]$, cyclooxygenase [26, 27], and histone acetyltransferases [28, 29]. It has been also demonstrated that AAs modulate the NF- $\kappa \mathrm{B}$ signaling pathway and inhibit tumor angiogenesis indicating that these compounds could be a therapeutic option in preventing or treating cancer [30-32].
To date, very few in vivo studies have tested the effects of AAs. Morais et al. [23] suggested that AAs induce gastroprotection primarily through an antioxidant mechanism at 10,30 , and $100 \mathrm{mg} / \mathrm{kg}$. We have previously demonstrated that doses of AAs less than $300 \mathrm{mg} / \mathrm{kg}$ do not produce biochemical, hematological, and mutagenic alterations in $\mathrm{BALB} / \mathrm{c}$ mice [33].

We hypothesized that AAs from CNSL would prevent DEP-induced lung inflammation. Based on this hypothesis, we analyzed the potential anti-inflammatory and antioxidant properties of supplementation with AAs in a subacute model of DEP-induced inflammation in mice.

\section{Materials and Methods}

2.1. Ethics Statement. This study was approved by the Ethical Committee of São Paulo University Medical School (permit number: 114/07). All animals received care in compliance with the "Principles of Laboratory Animal Care" published by the National Institutes of Health. All surgery procedure was performed under anesthesia, and all efforts were made to minimize suffering.

2.2. Animals. Six- to eight-week-old male BALB/c mice (20$25 \mathrm{~g}$ ) were obtained from the animal facility of São Paulo Medical School, University of São Paulo. Animals were housed in group cages at $22-26^{\circ} \mathrm{C}$ with a $12 \mathrm{~h} / 12 \mathrm{~h}$ light/dark cycle and received ad libitum water and commercial pellet food for small rodents from Nuvital (Nuvilab CR-1; Colombo, Brazil).

2.3. Plant Material. The cashews (Anacardium occidentale Linn.) were harvested at the Embrapa Tropical Agroindustry Experimental Station, located at Paraipaba, Ceará, Brazil, during the 2007 season. The fruits were from a commercial cultivar (CCP-76), whose genetic material is maintained on the Embrapa's germplasm bank. The fresh cashew apples were manually separated from the nut and were obtained as a kind gift from Dr. Edy Sousa de Brito (Embrapa, Fortaleza, Brazil). CNSL (300 g) was obtained by heating $1 \mathrm{~kg}$ of fruit $\left(175^{\circ} \mathrm{C}\right)$ in an oven for $45 \mathrm{~min}$. The cashew nuts oil ( $2 \mathrm{~L}$ ) was obtained from cashew nuts subjected to Soxhlet extraction with hexane (3h) [19].

2.4. Isolation of AAs from CNSL. Extracted CNSL (200 g) was dissolved in $5 \%$ aqueous methanol $(1200 \mathrm{~mL})$, and calcium hydroxide $(100 \mathrm{~g})$ was added while stirring. The mixture was kept at $50^{\circ} \mathrm{C}$ and stirred for $3 \mathrm{~h}$. The supernatant solution was monitored by two-dimensional thin layer chromatography for the absence of AAs. The precipitated calcium anacardate was filtered and washed with methanol. Calcium anacardate was dissolved in distilled water acidified with $11 \mathrm{M} \mathrm{HCl}$. The solution was extracted with ethyl acetate; the ethyl acetate layer was then washed with distilled water, dried over anhydrous sulfate, and concentrated under reduced pressure to yield $120 \mathrm{~g}$ of AAs mixture, as described by Paramashivappa et al. [34]. All structures were verified by comparing spectral and physical data with those previously reported in the literature [19] and by direct comparison with authentic 
Anacardic acid-1<smiles>C=CC/C=C/C/C=C/CCCCCCCc1cccc(O)c1C(=O)O</smiles>

(a)

Anacardic acid-3

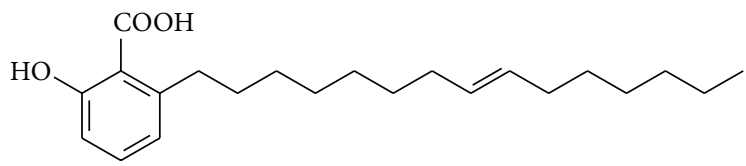

(c)
Anacardic acid-2

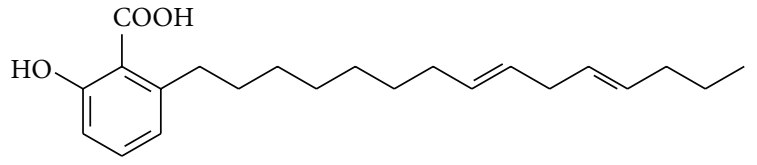

(b)

Anacardic acid-4

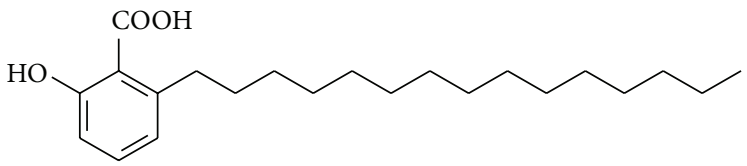

(d)

Figure 1: Chemical structure of anacardic acids.

samples. Figure 1 depicts the structure of the AAs isolated from CNSL.

2.5. DEP Collection. Diesel particles were collected from a bus from São Paulo city's metropolitan fleet after one day of routine operation. This bus was equipped with a Mercedes Benz MB1620, 210-hp engine with a Euro III emission profile, which lacked an electronic fuel injector. The diesel fuel used in São Paulo contains $500 \mathrm{ppm}$ of sulphur. The 6 to $7 \mu \mathrm{m}$ diesel particulate material was collected with a particle retainer (a bimetallic filter) that is used to test diesel vehicles to reduce PM emissions. Particulate material was stored at $4^{\circ} \mathrm{C}$ for toxicological and analytical studies. DEP was dissolved in saline at $10 \mathrm{mg} / \mathrm{mL}$ for $2 \mathrm{~h}$ through magnetic stirring and was sonicated for $30 \mathrm{~min}$. Next, DEP was diluted to $50 \mu \mathrm{g}$ in $10 \mu \mathrm{L}$ of saline and stored at $-20^{\circ} \mathrm{C}$ until further use. Characteristics of the DEP used in this study have previously been evaluated by energy-dispersive X-ray fluorescence spectrometry to determine the metal composition, as well as by atomic absorption spectrophotometry to assess polycyclic aromatic hydrocarbons $[7,35]$.

2.6. Exposure Protocol and Supplementation with AAs. Lung inflammation in male BALB/c mice was induced by intranasal instillation of $50 \mu \mathrm{g}$ of DEP diluted in $10 \mu \mathrm{L}$ of saline solution for 20 consecutive days. The control group received $10 \mu \mathrm{L}$ of saline solution during the same period. Ten days prior to the intranasal instillation procedure, animals were pretreated orally with 50,150, or $250 \mathrm{mg} / \mathrm{kg}$ of AAs from CNSL diluted in $100 \mu \mathrm{L}$ of cashew nut oil (CNO) or $100 \mu \mathrm{L}$ of CNO for 30 days. The three doses were selected based on previous dose-dependent studies in related specimens [23, 33, 36-39]. Eighty mice were assigned to five groups: (a) control (Ctrl) animals received an intranasal instillation of $10 \mu \mathrm{L}$ saline solution and were treated orally with $100 \mu \mathrm{L}$ of CNO (vehicle); (b) diesel exhaust particles (DEP) animals received an intranasal instillation of $50 \mu \mathrm{g} \mathrm{DEP} / 10 \mu \mathrm{L}$ of saline and were treated orally with $100 \mu \mathrm{L}$ of CNO; (c) diesel exhaust particles + AAs $50 \mathrm{mg} / \mathrm{kg}$ (DA50) animals received an intranasal instillation of $50 \mu \mathrm{g} \mathrm{DEP} / 10 \mu \mathrm{L}$ of saline and were treated orally with $50 \mathrm{mg} / \mathrm{kg}$ of AAs; (d) diesel exhaust particles + AAs $150 \mathrm{mg} / \mathrm{kg}$ (DA150) animals received an intranasal instillation of $50 \mu \mathrm{g} \mathrm{DEP} / 10 \mu \mathrm{L}$ of saline and were treated orally with $150 \mathrm{mg} / \mathrm{kg}$ of AAs; and (e) diesel exhaust particles + AAs $250 \mathrm{mg} / \mathrm{kg}$ (DA250) animals received an intranasal instillation of $50 \mu \mathrm{g} \mathrm{DEP} / 10 \mu \mathrm{L}$ of saline and were treated orally with $250 \mathrm{mg} / \mathrm{kg}$ of AAs. From each group, eight animals were used for bronchoalveolar lavage fluid (BALF) collection and histological and immunohistochemistry analysis of the lungs. The remaining eight animals were used for analyzing the activity of antioxidant enzymes in lung homogenates and in erythrocytes.

2.7. BALF Collection and Analysis. Twenty-four hours following the last DEP (or saline) intranasal instillation and supplementation with AAs (or CNO), animals were anesthetized by intramuscular injection of ketamine $(50 \mathrm{mg} / \mathrm{kg}$ ) and xylazine $(40 \mathrm{mg} / \mathrm{kg})$, tracheostomized, and cannulated for BALF collection. BALF samples $(1 \mathrm{~mL})$ were collected after washing the lungs with $1.5 \mathrm{~mL}$ of phosphate buffered saline (PBS). BALF samples were centrifuged at $850 \mathrm{rpm}$ for $10 \mathrm{~min}$ at $5^{\circ} \mathrm{C}$, the supernatant was stored at $-70^{\circ} \mathrm{C}$, and the cell pellet was resuspended in $300 \mu \mathrm{L}$ of PBS. Total cell counts were performed using the Neubauer hemocytometer cell count chamber (Neubauer Improved Chamber, Labor Optik, Friedrichsdorf, Germany). Differential cell count was performed by microscopic examination of BALF samples prepared on cytocentrifuge slides (Cytospin-2, Shandon Instruments, Sewickley, PA) stained with Diff Quik (Muto Kagaku Co., Tokyo, Japan). Three hundred cells were counted per slide. The levels of IL-1 $\beta$, tumor necrosis factor alpha (TNF- $\alpha$ ), IL-6, and IL-10 in the BALF supernatants were determined. Cytokine concentrations were quantified using an enzyme-linked immunosorbent assay according to the manufacturer's protocol. The kit for IL-1 $\beta$ detection was obtained from eBioscience (San Diego, CA, USA), and the kits for TNF- $\alpha$, IL- 6 and IL-10 detection were purchased from BD Biosciences (Franklin Lakes, NJ, USA). Following BALF collection, the animals were sacrificed by exsanguinations, and the lungs were removed for histological and immunohistochemistry analysis. 
2.8. Antioxidants Enzymes Determinations. Twenty-four hours following the final intranasal instillation of DEP (or saline) and supplementation with AAs (or CNO), animals were anesthetized, and the peripheral blood was collected. Then, the lungs were removed after perfusion with saline solution and were stored at $-80^{\circ} \mathrm{C}$. Enzymatic activities of glutathione peroxidase (GPx), glutathione reductase (GR), glutathione S-transferase (GST), and catalase (CAT) were determined in the lung homogenates and in erythrocytes using a spectrophotometric method. GPx activity was assessed with the procedure described by Flohé and Günzler [40]. Tert-butyl hydroperoxide was used as substrate, and the formation of oxidized glutathione (GSSG) was indirectly monitored spectrophotometrically as NAPDH consumption at $340 \mathrm{~nm}$ for $5 \mathrm{~min}$. GR activity was assayed according to Carlberg and Mannervik [41]. The reduction of GSSG to GSH was measured as the consumption of NADPH and monitored spectrophotometrically at $37^{\circ} \mathrm{C}$ for $10 \mathrm{~min}$ at $340 \mathrm{~nm}$. The GST activity assay, which measured the conjugation of 1-chloro-2,4-dinitrobenzene (CDNB) with reduced glutathione, was conducted according to Habig et al. [42]. The formation of the complex was monitored spectrophotometrically at $25^{\circ} \mathrm{C}$ for $5 \mathrm{~min}$ at $340 \mathrm{~nm}$. GPx, GR, and GST assays were performed in a PowerWave $\times 340$ Spectrophotometer (Bio-Tek Instruments INC, software KC4 v3.0). Catalase activity was evaluated by measuring the consumption of hydrogen peroxide [43]. The decrease in absorbance was monitored at $25^{\circ} \mathrm{C}$ for $30 \mathrm{~s}$ at $240 \mathrm{~nm}$ in a spectrophotometer (Biochrom Libra S12).

2.9. Lung Histology, Morphometry and Immunohistochemistry. Lungs were fixed in formalin and embedded in paraffin. Five-micrometer sections were stained with hematoxylin and eosin for the quantification of neutrophil density.

2.9.1. Morphometry. For conventional morphometry, an eyepiece with a coherent system of 50 lines and 100 points with a known area attached to the ocular lens of the microscope was used. The density of neutrophils in the alveolar parenchyma was assessed by point counting. Using a 100-point grid with a known area $\left(7,000 \mu \mathrm{m}^{2}\right.$ at $1000 \mathrm{x}$ magnification) attached to the microscope ocular lens, we counted the number of points hitting alveolar tissue in each field. Alveolar tissue area in each field was calculated as the number of points hitting alveolar tissue as a proportion of the total grid area. Neutrophil density was determined as the number of neutrophils in each field divided by the tissue area. Measurements are expressed as cells $/ \mathrm{mm}^{2}$. Counting was performed in 40 fields of alveolar parenchyma for each animal at a magnification of 1000x [44].

2.9.2. Immunohistochemistry. Lung sections were deparaffinized and hydrated. After blocking for endogenous peroxidase, antigen retrieval was performed with either hightemperature citrate buffer $(\mathrm{pH}=6.0)$, tris-EDTA or trypsin. The following primary antibodies were used in the study: goat 8-epi-PGF $2 \alpha$ (8-isoprostane antibody) (goat, 1:500, Oxford Biomedical Research, Oxford, England), mouse Mac2 (macrophage antibody) (mouse, $1: 100,000$, Cedarlane, ON,
Canada), goat TNF- $\alpha$ (goat, 1:2,000, Santa Cruz Biotechnology, CA, USA), rabbit VCAM-1 (rabbit, 1:600, Santa Cruz Biotechnology, CA, USA), rabbit NF- $\kappa$ B p65 (rabbit, 1:200, Santa Cruz Biotechnology, CA, USA), and mouse CXCL1/KC (keratinocyte chemoattractant (KC) antibody) (mouse, 1:100, Cedarlane, MN, USA). The VECTASTAIN ABC Kit, Vector Laboratories (Burlingame, CA, USA) was used as the secondary antibody, and 3,3-Diaminobenzidine (DAB, Sigma, St Louis, Mo, USA), was used as the chromogen. Tissue sections were counterstained with Harris hematoxylin (Merck, Darmstadt, Germany). For negative controls, the primary antibody was omitted from the procedure, and bovine serum albumin was used instead.

2.9.3. Image Analysis. Areas positively immunostained for 8 -isoprostane, macrophage cell density, and cells expressing $\mathrm{KC}, \mathrm{TNF}-\alpha$, and NF- $\kappa \mathrm{B}$ in the alveolar parenchyma, as well as the areas positively immunostained for VCAM and KC in peribronchiolar vessels, were determined using image analysis. Analyses were performed using Image-Pro Plus 4.1 software for Windows (Media Cybernetics, Silver Spring, $\mathrm{Md}$ ) on a personal computer connected to a digital camera (Olympus Q-Color 5, Tokyo, Japan) coupled to a light microscope. We counted the number of positively stained cells in the alveolar tissue in each field. The 8-isoprostane-stained regions and the alveolar tissue areas were calculated for 20 fields (alveolar tissue) at a magnification of 200x. Data are expressed as cell density per alveolar tissue area $\left(\right.$ cells $\left./ \mu \mathrm{m}^{2}\right)$ or macrophages cell density per alveolar area $\left(\right.$ cells $/ \mathrm{mm}^{2}$ ) and 8-isoprostane immunostained area per alveolar tissue area $\left(\mu \mathrm{m}^{2} / \mu \mathrm{m}^{2}\right)$. We also assessed VCAM and KC positive areas in five peribronchiolar vessels [45]. The results were expressed as immunostained area per perimeter of the outer muscular layer of the vessel $\left(\mu \mathrm{m}^{2} / \mu \mathrm{m}\right)$. Slides were coded for blind analysis. All measurements were performed by the same observer.

2.10. Statistical Analyses. Statistical analyses were performed with SPSS 15.0 software (SPSS, Inc., Chicago, IL, USA). Data are expressed as the means \pm standard deviation (SD) or as medians (interquartile range), unless otherwise specified. Comparisons between Ctrl and DEP, as well as between DEP versus DA50, DEP versus DA150, and DEP versus DA250, were performed using unpaired Student's $t$-tests (parametric data) or Mann-Whitney tests (nonparametric data). A $P$ value of $<0.05$ was considered significant.

\section{Results}

3.1. BALF. As shown in Table 1, significant differences were not detected in BALF cell types between the Ctrl and DEP groups; however, an increase was observed in the number of neutrophils in the DA250 group and of lymphocytes in DA150 group compared to the DEP-treated group $(P<0.05)$. In the BALF supernatant, however (Table 2 ), levels of TNF- $\alpha$ were 6 -fold higher in DEP-treated mice than in the Ctrl mice $(P<$ $0.001)$. Mice treated with $50 \mathrm{mg} / \mathrm{kg}$ of AAs demonstrated decreased TNF- $\alpha$ levels, compared with mice treated with 
TABLE 1: Effects of supplementation with anacardic acids on the cellular profile of the bronchoalveolar lavage fluid in mice instilled with diesel exhaust particles.

\begin{tabular}{lcccrr}
\hline Differential cells $\left(\times 10^{4}\right)$ & Ctrl & DEP & DA50 & DA150 & DA250 \\
\hline Total Cells & $5.88 \pm 2.61$ & $6.76 \pm 2.05$ & $8.10 \pm 1.61$ & $8.74 \pm 1.42$ & $0.52 \pm 0.99$ \\
Eosinophils & $0.00(0.00)$ & $0.00(0.06)$ & $0.00(0.02)$ & $0.19)$ & $0.00(0.00)$ \\
Neutrophils & $0.04(0.24)$ & $0.12(0.13)$ & $0.21(0.36)$ & $0.20(0.31)$ & $0.23(0.10)^{\mathrm{a}}$ \\
Lymphocytes & $0.63 \pm 0.42$ & $0.47 \pm 0.71$ & $0.99 \pm 0.56$ & $1.33 \pm 0.64^{\mathrm{a}}$ & $1.17 \pm 0.80$ \\
Macrophages & $4.38 \pm 2.24$ & $5.36 \pm 1.77$ & $5.86 \pm 1.06$ & $6.33 \pm 1.32$ & $5.37 \pm 0.73$ \\
Caliciform cells & $0.41 \pm 0.26$ & $0.47 \pm 0.41$ & $0.57 \pm 0.36$ & $0.19 \pm 0.19$ & $0.24 \pm 0.19$ \\
Ciliary cells & $0.31 \pm 0.27$ & $0.26 \pm 0.17$ & $0.41 \pm 0.20$ & $0.54 \pm 0.47$ & $0.44 \pm 0.27$ \\
\hline
\end{tabular}

Values are expressed as the means \pm SD or as medians (interquartile range). ${ }^{a} P<0.05$ significant difference compared to DEP. AAs: anacardic acids. Ctrl: control, animals received an intranasal instillation of $10 \mu \mathrm{L}$ saline solution and were treated orally with $100 \mu \mathrm{L}$ of cashew nut oil (CNO). DEP: diesel exhaust particles, intranasal instillation of $50 \mu \mathrm{g} \mathrm{DEP} / 10 \mu \mathrm{L}$ of saline and treated orally with $100 \mu \mathrm{L}$ of CNO. DA50: intranasal instillation of $50 \mu \mathrm{g}$ DEP/10 $\mu \mathrm{L}$ of saline and treated orally with $50 \mathrm{mg} / \mathrm{kg}$ of AAs. DA150: intranasal instillation of $50 \mu \mathrm{g} \mathrm{DEP} / 10 \mu \mathrm{L}$ of saline and treated orally with $150 \mathrm{mg} / \mathrm{kg}$ of AAs. DA250: intranasal instillation of $50 \mu \mathrm{g} \mathrm{DEP} / 10 \mu \mathrm{L}$ of saline and treated orally with $250 \mathrm{mg} / \mathrm{kg}$ of AAs.

TABLE 2: Effects of supplementation with anacardic acids on cytokine concentration in the bronchoalveolar lavage fluid in mice instilled with diesel exhaust particles.

\begin{tabular}{lccccc}
\hline Cytokines & Ctrl & DEP & DA50 & DA150 & DA250 \\
\hline IL-1 $\beta(\rho \mathrm{g} / \mathrm{mL})$ & $189.40 \pm 43.56$ & $228.52 \pm 66.25$ & $181.51 \pm 66.30$ & $451.45 \pm 138.14^{\mathrm{b}}$ & $459.72 \pm 175.81^{\mathrm{b}}$ \\
TNF- $\alpha(\rho \mathrm{g} / \mathrm{mL})$ & $19.84 \pm 10.87$ & $118.86 \pm 54.24^{\mathrm{a}}$ & $25.83 \pm 6.42^{\mathrm{b}}$ & $112.44 \pm 37.73$ & $130.83 \pm 64.67$ \\
IL-6 $(\rho \mathrm{g} / \mathrm{mL})$ & $61.96 \pm 40.73$ & $74.84 \pm 42.84$ & $62.58 \pm 46.53$ & $118.11 \pm 77.08$ & $103.04 \pm 51.44$ \\
IL-10 $(\rho \mathrm{g} / \mathrm{mL})$ & $1126.36 \pm 463.89$ & $1526.35 \pm 538.16$ & $1362.49 \pm 217.83$ & $1862.99 \pm 646.02$ & $1508.36 \pm 499.59$ \\
\hline
\end{tabular}

Values are expressed as the means \pm SD. ${ }^{a} P<0.001$ statistical difference compared to Ctrl. ${ }^{b} P<0.05$ significant difference compared to DEP. AAs: anacardic acids. Ctrl: control, animals received an intranasal instillation of $10 \mu \mathrm{L}$ saline solution and were treated orally with $100 \mu \mathrm{L}$ of cashew nut oil (CNO). DEP: diesel exhaust particles, intranasal instillation of $50 \mu \mathrm{g} \mathrm{DEP} / 10 \mu \mathrm{L}$ of saline and treated orally with $100 \mu \mathrm{L}$ of CNO. DA50: intranasal instillation of $50 \mu \mathrm{g}$ DEP/10 $\mu \mathrm{L}$ of saline and treated orally with $50 \mathrm{mg} / \mathrm{kg}$ of AAs. DA150: intranasal instillation of $50 \mu \mathrm{g}$ DEP/10 $\mu \mathrm{L}$ of saline and treated orally with $150 \mathrm{mg} / \mathrm{kg}$ of AAs. DA250: intranasal instillation of $50 \mu \mathrm{g}$ DEP/10 $\mu \mathrm{L}$ of saline and treated orally with $250 \mathrm{mg} / \mathrm{kg}$ of AAs.

DEP $(P<0.002)$. The increased levels of IL-1 $\beta$ were observed in the DA150 and DA250 groups, compared with the DEP group $(P<0.05)$. Equivalent levels of IL-6 and IL-10 levels were detected in BALF across all of the groups that were examined.

3.2. Antioxidant Enzyme Activities. Enzymatic analysis for GR (Figure 2(a)), GPx (Figure 2(b)), GST (Figure 2(c)), and CAT (Figure 2(d)) in lung homogenates all revealed the same pattern of activity. DEP-treated mice demonstrated decreased enzymatic activities, compared with the Ctrl mice $(P<0.05)$. Groups that received an oral supplementation with 50, 150, or $250 \mathrm{mg} / \mathrm{kg}$ of AAs showed significantly increased activity levels for all enzymes, compared with the DEP group $(P<$ $0.05)$, especially for GST and CAT activities $(P<0.001)$. The DEP group showed increased activity of GR in the peripheral blood samples (Figure 3 ) relative to the Ctrl group $(P<0.05)$.

3.3. Inflammatory Response in Alveolar Parenchyma and in Peribronchiolar Vessels. The panoramic view of the inflammatory response caused by $50 \mu \mathrm{g}$ of DEP in the lung tissue compared to Ctrl group was demonstrated in Figure 4. Compared with the Ctrl group, the DEP-treated group demonstrated a 3 -fold increase in the influx of neutrophils $(P<0.001$; Figure 5); however, a decrease in the density of neutrophils was observed in the DA50 and DA150 groups relative to the DEP-treated group $(P<0.001$, Figure 6(a)).
A statistically significant difference was not detected for the density of cells expressing macrophages (Figure 6(b)) in alveolar parenchyma among the DEP and Ctrl groups. Additionally, a decrease in macrophage density was observed in the DA50 and DA150 groups, compared with the DEP group $(P<0.05)$. A significant difference was not detected for the 8 -isoprostane-positive area between the DEP and Ctrl groups (Figure 7(a)), although the group that received $250 \mathrm{mg} / \mathrm{kg}$ of AAs demonstrated increased values, compared with those for the DEP group $(P<0.05)$. A significant difference was not detected for cells immunostained for KC (Figure 7(b)) in the DEP group, compared with the Ctrl group. DA50 and DA250 groups demonstrated a decreased KC-positive cells, compared with the DEP group $(P<0.001$ and $P<0.05$, resp.). There was no significant difference for cells staining positively for the expression of TNF- $\alpha$ (Figure 7(c)) and NF$\kappa \mathrm{B}$ (Figure $7(\mathrm{~d})$ ) in the lung tissue among the groups. In peribronchiolar vessels (Figure 8(a)), DEP exposure resulted in increased VCAM expression (2-fold), compared with that in the Ctrl group $(P<0.05)$. All animals that received doses of AAs demonstrated decreased expression, compared with those in the DEP-treated animals $(P<0.05)$ as depicted for the DA50 group (Figure 9). A significant difference was not detected for areas positively immunostained for KC (Figure 8(b)) in peribronchiolar vessels in the DEP-treated group, compared with the Ctrl group; however, decreased expression of KC was observed in DA50- and DA150-treated 


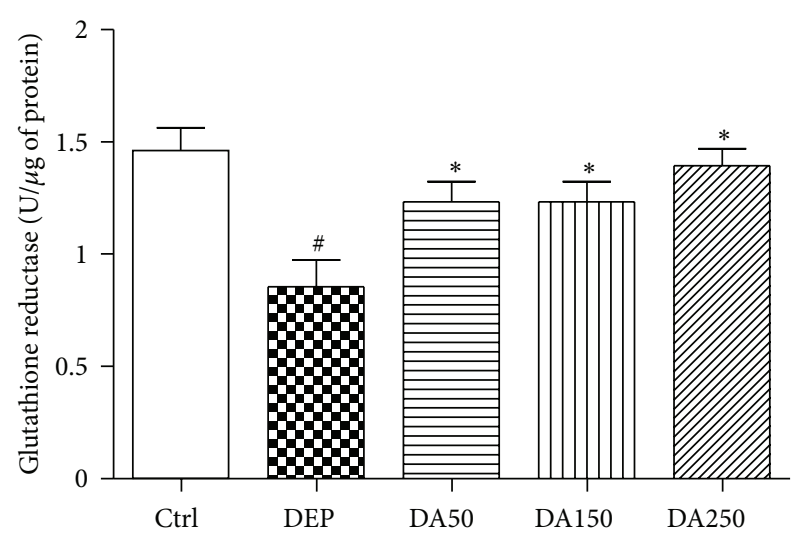

(a)

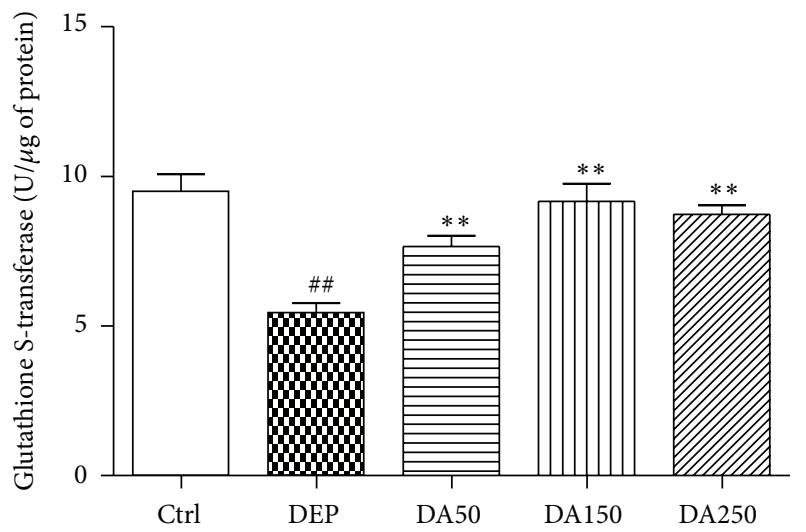

(c)

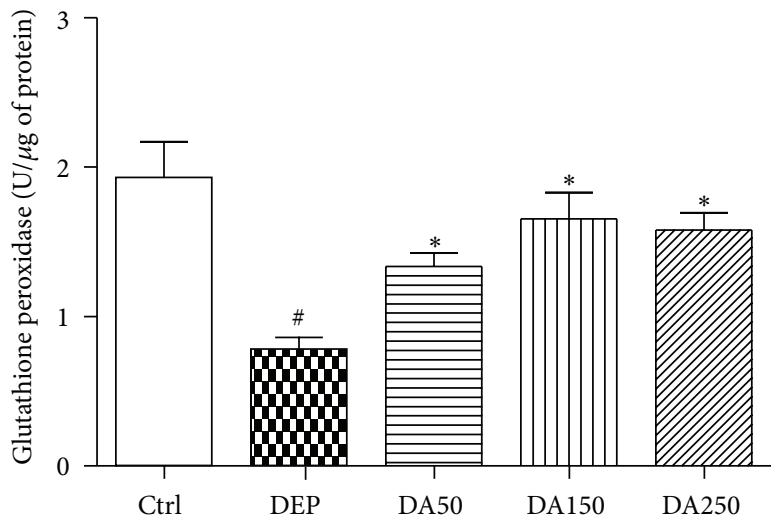

(b)

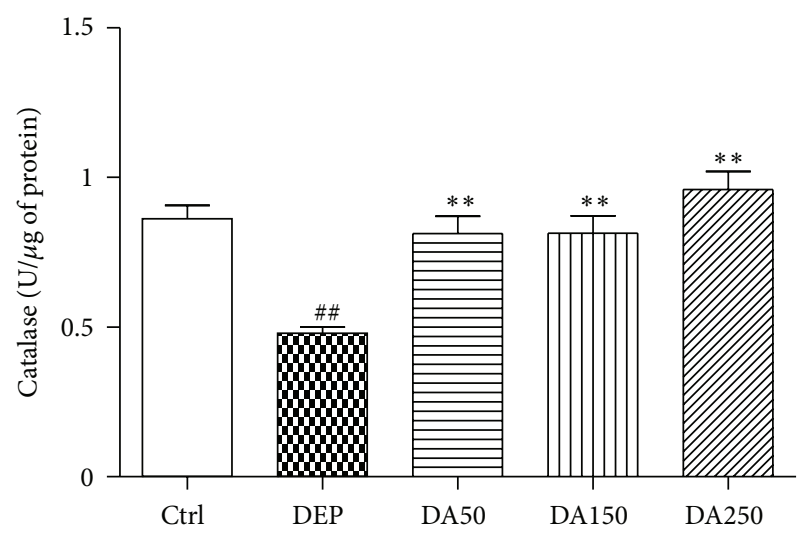

(d)

Figure 2: Glutathione reductase (a), glutathione peroxidase (b), glutathione S-transferase (c), and catalase (d) activities in lungs. Values represent means \pm SEM. Ctrl: control; animals received an intranasal instillation of $10 \mu \mathrm{L}$ saline solution and were treated orally with $100 \mu \mathrm{L}$ of cashew nut oil (CNO). DEP: diesel exhaust particles; intranasal instillation of $50 \mu \mathrm{g} \mathrm{DEP} / 10 \mu \mathrm{L}$ of saline and treated orally with $100 \mu \mathrm{L}$ of CNO. DA50: intranasal instillation of $50 \mu \mathrm{g} \mathrm{DEP} / 10 \mu \mathrm{L}$ of saline and treated orally with $50 \mathrm{mg} / \mathrm{kg}$ of AAs. DA150: intranasal instillation of $50 \mu \mathrm{g} \mathrm{DEP} / 10 \mu \mathrm{L}$ of saline and treated orally with $150 \mathrm{mg} / \mathrm{kg}$ of AAs. DA250: intranasal instillation of $50 \mu \mathrm{g}$ DEP/10 $\mu \mathrm{L}$ of saline and treated orally with $250 \mathrm{mg} / \mathrm{kg}$ of AAs. ${ }^{\#} P<0.05$ relative to Ctrl. ${ }^{*} P<0.05$ relative to DEP. ${ }^{\# \#} P<0.001$ relative to Ctrl. ${ }^{* *} P<0.001$ relative to DEP.

mice, compared with the DEP-treated mice $(P<0.001$ and $P<0.05$, resp.).

\section{Discussion}

In the present study, we demonstrated that AAs induce antioxidant and anti-inflammatory responses in a mouse model of DEP-induced lung tissue damage. Thirty days of oral supplementation with 50,150 , or $250 \mathrm{mg} / \mathrm{kg}$ of AAs prevented the decrease in GR, GPx, GST, and CAT activities and decreased the expression of VCAM in this model of subacute DEPinduced lung inflammation. At the systemic level (peripheral blood), however, the same protective effects on antioxidant enzymes were not observed.

Animals that received a $50 \mathrm{mg} / \mathrm{kg}$ dose of AAs demonstrated decreased levels of neutrophils and TNF- $\alpha$ in the lung parenchyma and in the BALF supernatant, respectively. In this model of subacute, low DEP exposure, the lowest dose of AAs $(50 \mathrm{mg} / \mathrm{kg})$ appears to be the most effective. To our knowledge, this is the first study to demonstrate the antioxidant and anti-inflammatory properties of AAs in lung tissue in vivo.

We consider our exposure model relevant, because it reflects the urban scenario of a megacity, such as São Paulo. Although the World Health Organization recommends $20 \mu \mathrm{g} / \mathrm{m}^{3}$ of particulate matter less than $10 \mu \mathrm{m}\left(\mathrm{PM}_{10}\right)$, the mean annual concentration of $\mathrm{PM}_{10}$ in São Paulo is approximately $40 \mu \mathrm{g} / \mathrm{m}^{3}$. During the winter, the levels of $100 \mu \mathrm{g} / \mathrm{m}^{3}$ or above are frequently observed in this city $[7,46]$.

Results from this murine model of increased oxidative burden caused by DEP and prevented by AAs supplementation provide important information about the GSH-enzymes redox cycle. Oral supplementation with AAs from CNSL (50, 150 , and $250 \mathrm{mg} / \mathrm{kg}$ ) prevented the decrease in the antioxidant enzymes GR, GPx, GST, and CAT caused by DEP exposure.

The GSH redox system is the most important antioxidant defense system in lung cells [47]. GSH-associated enzymes present in the lower respiratory tract act as a first line of defense against sustained oxidative challenges $[48,49]$. This system uses GSH as a substrate for GPx and GST in the 


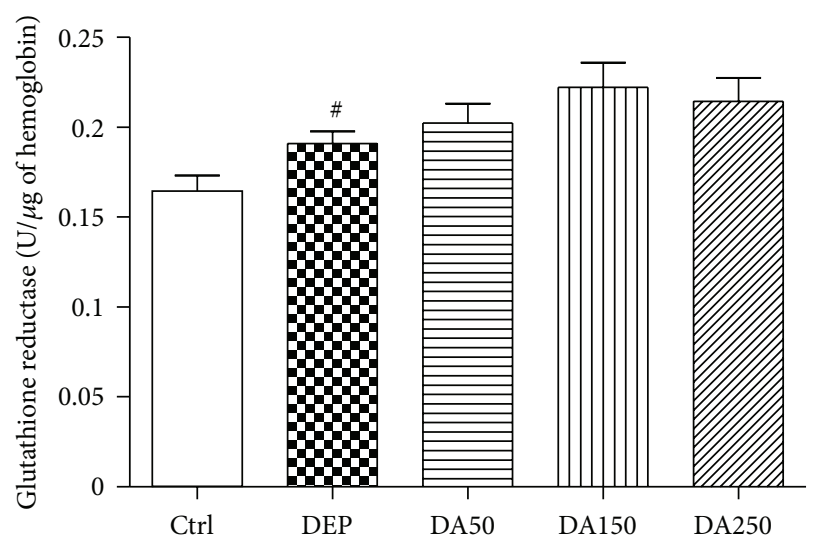

(a)

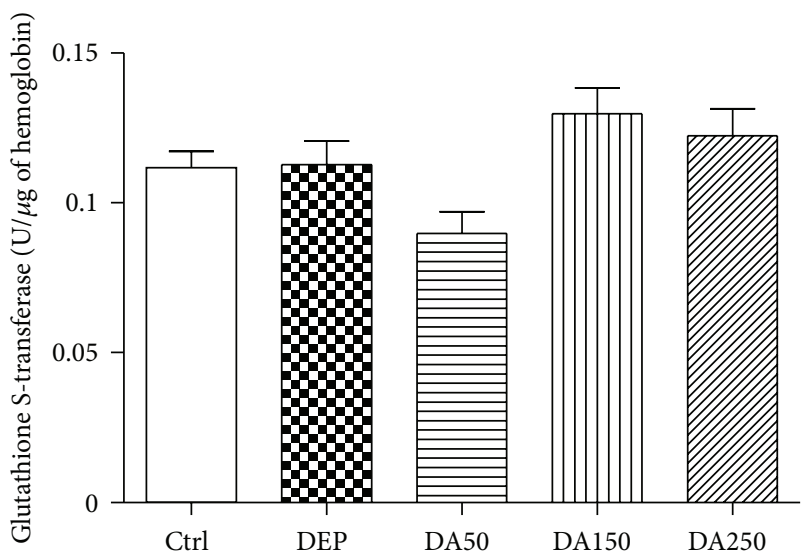

(c)

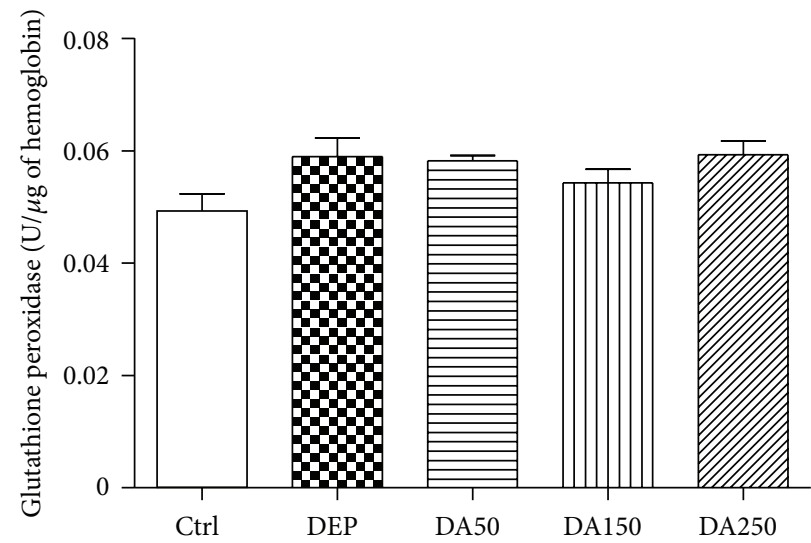

(b)

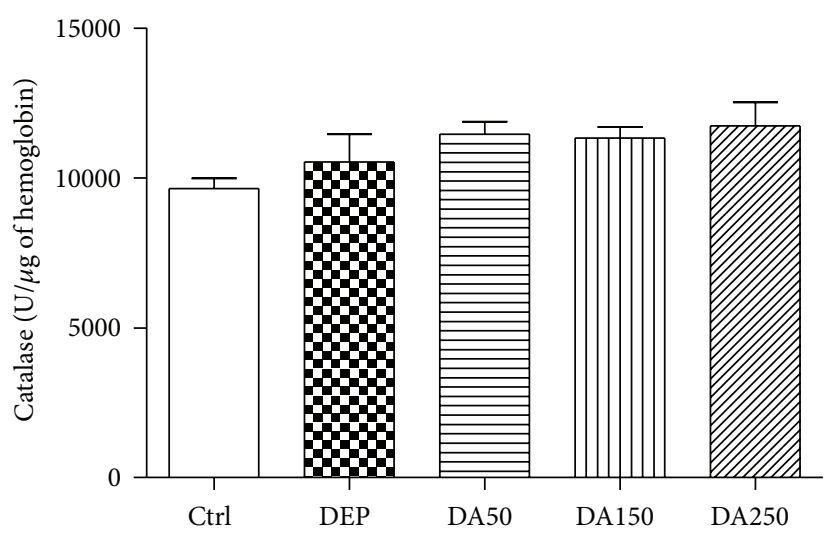

(d)

Figure 3: Glutathione reductase (a), glutathione peroxidase (b), glutathione S-transferase (c), and catalase (d) activities in blood. Values represent means \pm SEM. Ctrl: control; animals received an intranasal instillation of $10 \mu \mathrm{L}$ saline solution and were treated orally with $100 \mu \mathrm{L}$ of cashew nut oil (CNO). DEP: diesel exhaust particles; intranasal instillation of $50 \mu \mathrm{g} \mathrm{DEP} / 10 \mu \mathrm{L}$ of saline and treated orally with $100 \mu \mathrm{L}$ of CNO. DA50: intranasal instillation of $50 \mu \mathrm{g} \mathrm{DEP} / 10 \mu \mathrm{L}$ of saline and treated orally with $50 \mathrm{mg} / \mathrm{kg}$ of AAs. DA150: intranasal instillation of $50 \mu \mathrm{g} \mathrm{DEP} / 10 \mu \mathrm{L}$ of saline and treated orally with $150 \mathrm{mg} / \mathrm{kg}$ of AAs. DA250: intranasal instillation of $50 \mu \mathrm{g}$ DEP/10 $\mu \mathrm{L}$ of saline and treated orally with $250 \mathrm{mg} / \mathrm{kg}$ of AAs. ${ }^{\#} P<0.05$ relative to Ctrl.

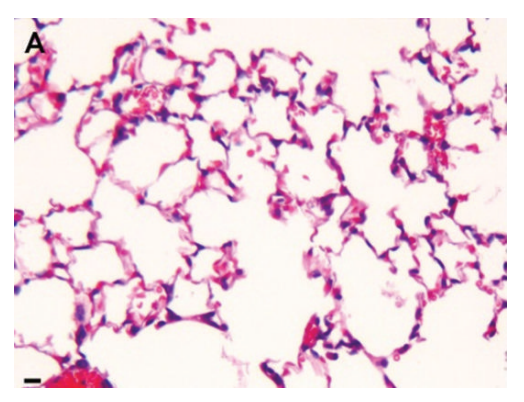

(a)

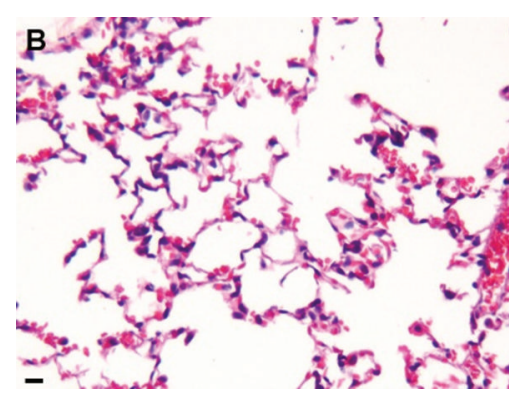

(b)

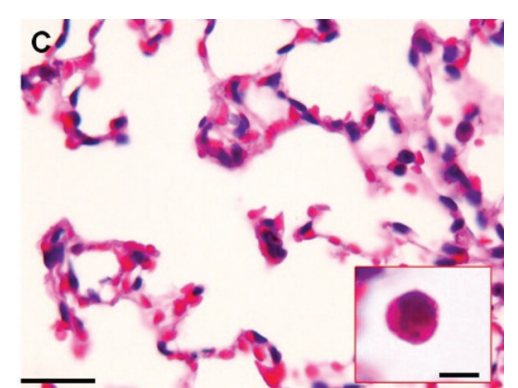

(c)

FIGURE 4: Photomicrographs showing a panoramic view of the inflammatory response in the lung tissue caused by DEP. The DEP group (b) demonstrated increased inflammatory response compared with the Ctrl group in the alveolar parenchyma (a). In detail (c), diesel particles phagocytized by a macrophage in the lung of an animal treated with DEP for 20 days. A black spot of anthracotic pigment can be observed in the inset $(\mathrm{H} \& \mathrm{E})$. Scale bars $=25 \mu \mathrm{m}$. 


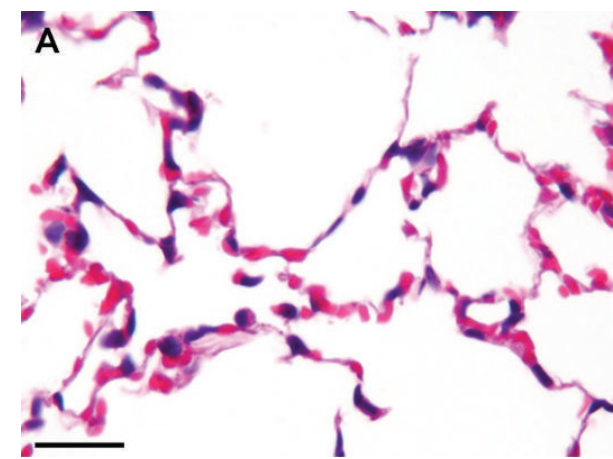

(a)

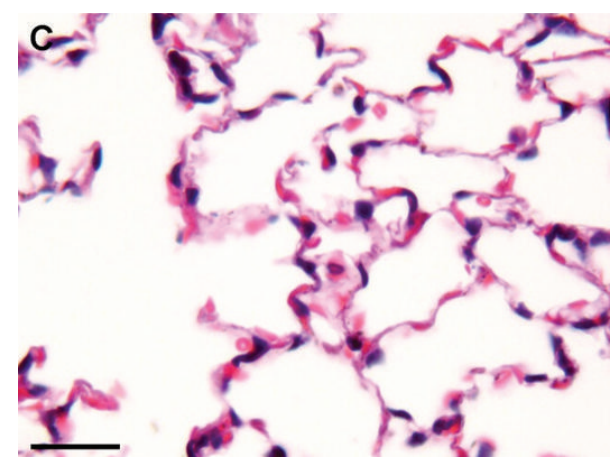

(c)

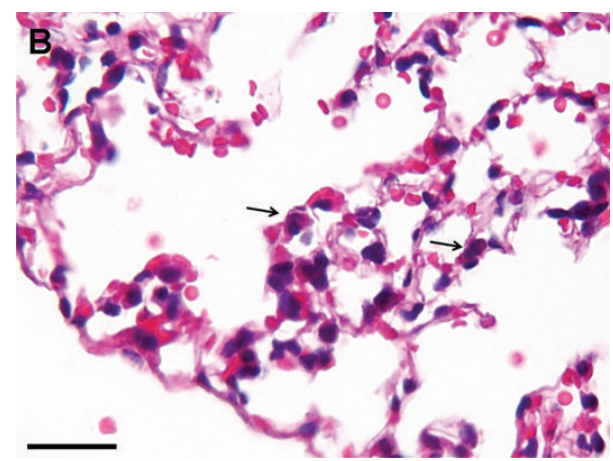

(b)

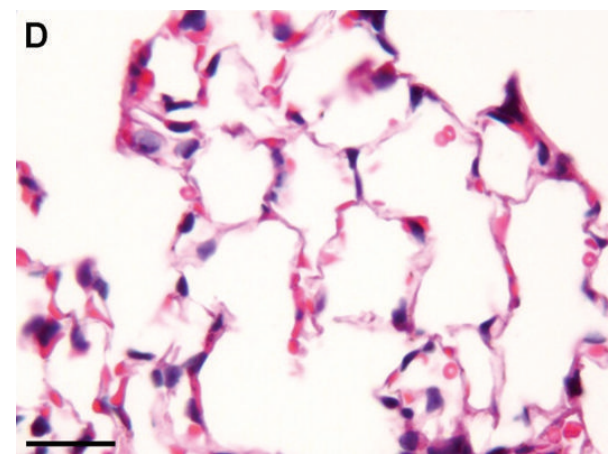

(d)

FIGURE 5: Photomicrographs showing the neutrophil density in lung tissue. The DEP group (b) demonstrated increased neutrophil density (in detail, the arrows are indicating some neutrophils) compared with the Ctrl group (a). Oral supplementation with 50 and $150 \mathrm{mg} / \mathrm{kg}$ of AAs was able to reduce the influx of neutrophils in lung tissue (c and d, resp.) (H\&E). Scale bars $=25 \mu \mathrm{m}$.

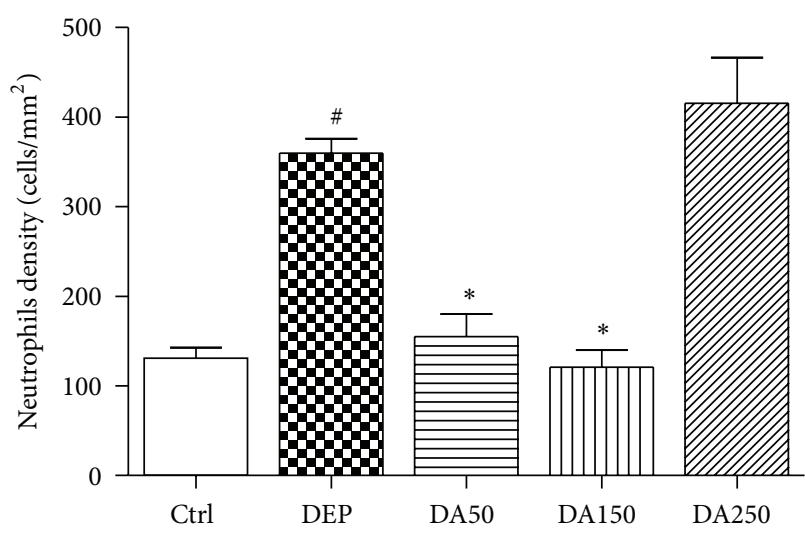

(a)

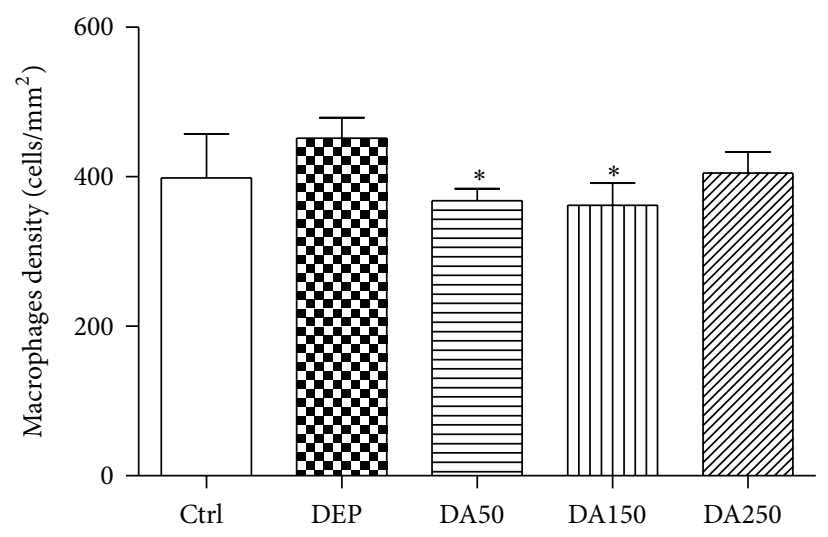

(b)

FIGURE 6: Influx of neutrophils (a) and macrophages (b) in the alveolar parenchyma. Values represent means \pm SEM. Ctrl: control; animals received an intranasal instillation of $10 \mu \mathrm{L}$ saline solution and were treated orally with $100 \mu \mathrm{L}$ of cashew nut oil (CNO). DEP: intranasal instillation of $50 \mu \mathrm{g} \mathrm{DEP} / 10 \mu \mathrm{L}$ of saline and treated orally with $100 \mu \mathrm{L}$ of CNO. DA50: intranasal instillation of $50 \mu \mathrm{g} \mathrm{DEP} / 10 \mu \mathrm{L}$ of saline and treated orally with $50 \mathrm{mg} / \mathrm{kg}$ of AAs. DA150: intranasal instillation of $50 \mu \mathrm{g}$ DEP/10 $\mu \mathrm{L}$ of saline and treated orally with $150 \mathrm{mg} / \mathrm{kg}$ of AAs. DA250: intranasal instillation of $50 \mu \mathrm{g} \mathrm{DEP} / 10 \mu \mathrm{L}$ of saline and treated orally with $250 \mathrm{mg} / \mathrm{kg}$ of AAs. ${ }^{\#} P<0.001$ relative to Ctrl. ${ }^{*} P<0.05$ relative to DEP. 


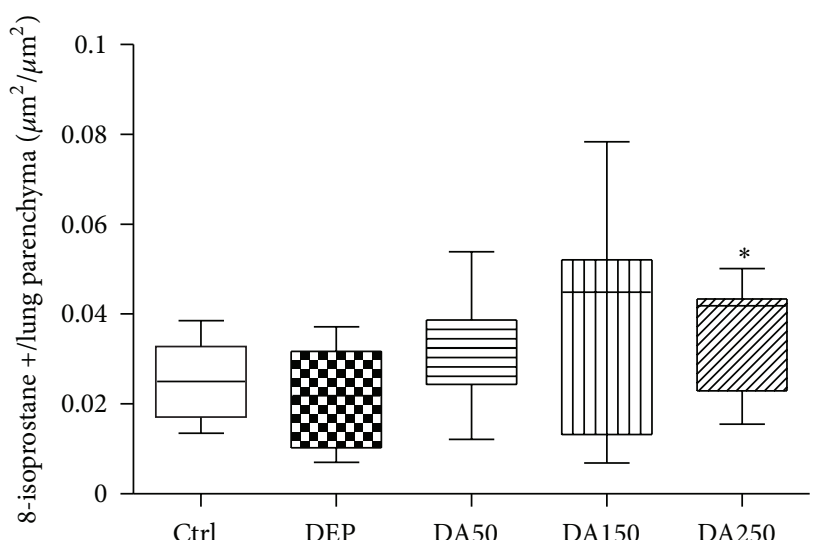

(a)

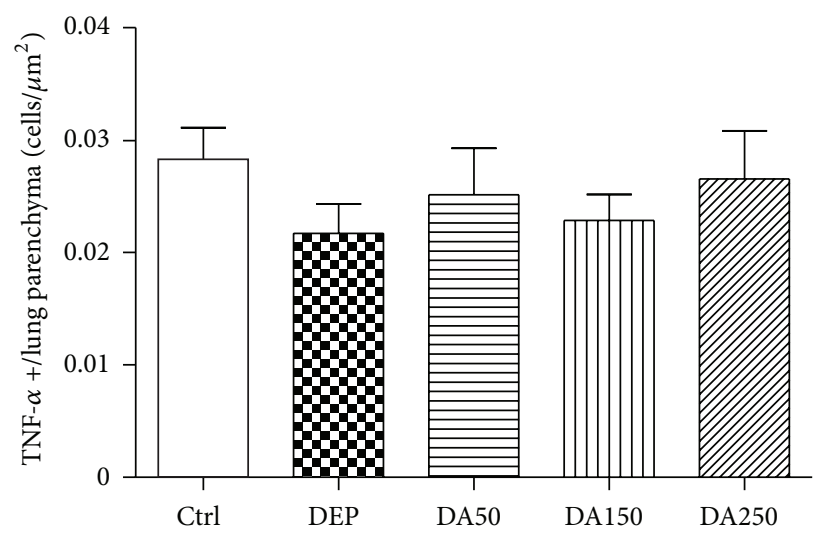

(c)

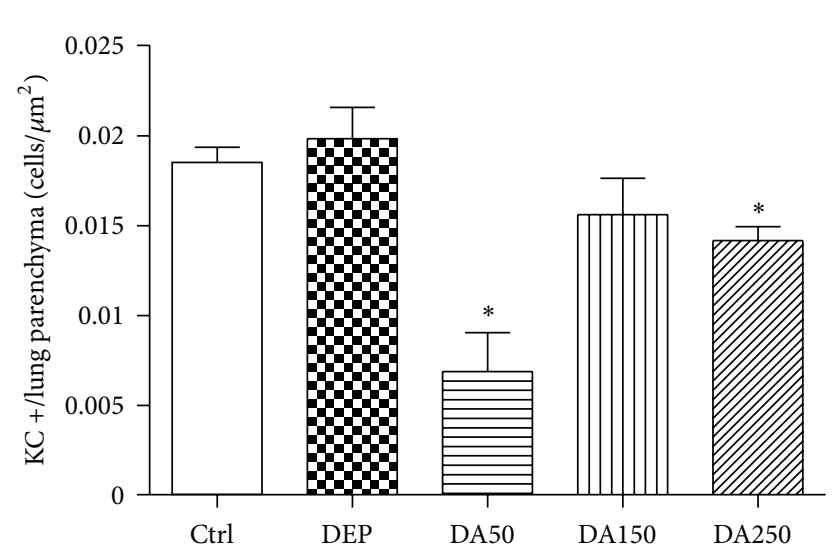

(b)

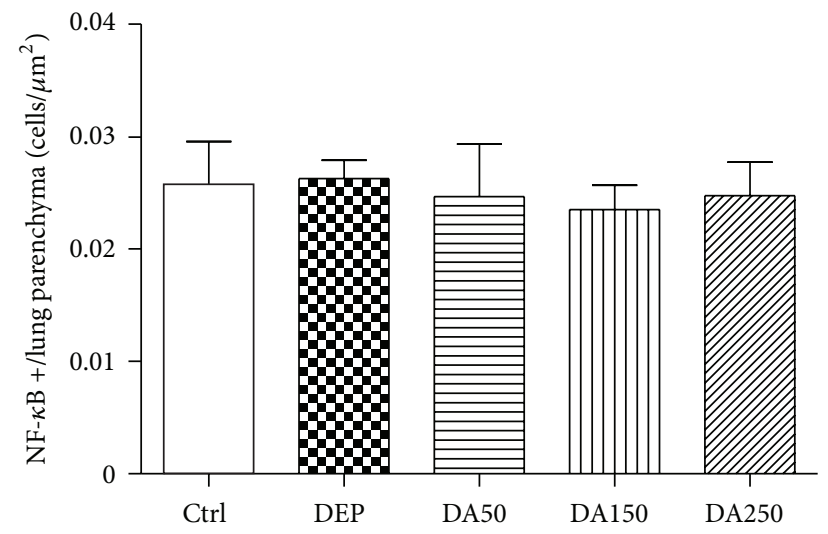

(d)

FIgURE 7: 8 -isoprostane (a), KC (b), TNF- $\alpha$ (c) and NF- $\kappa$ B (d) in the alveolar parenchyma. Values represent means \pm SEM or medians (interquartile range). Ctrl: control; animals received an intranasal instillation of $10 \mu \mathrm{L}$ saline solution and were treated orally with $100 \mu \mathrm{L}$ of cashew nut oil (CNO). DEP: intranasal instillation of $50 \mu \mathrm{g} \mathrm{DEP} / 10 \mu \mathrm{L}$ of saline and treated orally with $100 \mu \mathrm{L}$ of CNO. DA50: intranasal instillation of $50 \mu \mathrm{g} \mathrm{DEP} / 10 \mu \mathrm{L}$ of saline and treated orally with $50 \mathrm{mg} / \mathrm{kg}$ of AAs. DA150: intranasal instillation of $50 \mu \mathrm{g}$ DEP/10 $\mu \mathrm{L}$ of saline and treated orally with $150 \mathrm{mg} / \mathrm{kg}$ of AAs. DA250: intranasal instillation of $50 \mu \mathrm{g}$ DEP/10 $\mu \mathrm{L}$ of saline and treated orally with $250 \mathrm{mg} / \mathrm{kg}$ of AAs. KC: keratinocyte chemoattractant. TNF- $\alpha$ : tumor necrosis factor-alpha. NF- $\kappa$ B: nuclear factor-kappa B. ${ }^{\#} P<0.001$ relative to Ctrl. ${ }^{*} P<0.05$ relative to DEP.

detoxification of peroxides, including $\mathrm{H}_{2} \mathrm{O}_{2}$, lipid peroxides, and xenobiotic metabolites (such as the ones present in the composition of particulates) $[50,51]$. Catalase is an important enzyme responsible for the specific detoxification of $\mathrm{H}_{2} \mathrm{O}_{2}$.

All of these antioxidant enzymes exhibit decreased activity in the lung tissue following DEP damage but were positively influenced by supplementation with AAs. The same protective effects, however, were not observed in the peripheral blood; only GR activity remained increased in the DEP group compared to the Ctrl group. Several hypotheses may be used to justify this observed discrepancy between lung tissue and systemic responses: (1) DEP exposure only induced local effects in the lung tissue; (2) after $24 \mathrm{~h}$, at sacrifice, the activities of GPx, GST, and CAT returned to basal levels; it was not possible, however, to stabilize the activity of GR, which remained elevated in the DEP group, compared with the other treatment groups, suggesting that this enzyme, yet, acted in the reposition of GSH levels; (3) the partial pressure of oxygen in the arterial blood $\left(\mathrm{PaO}_{2}\right)$ in the lung is higher than $\mathrm{PaO}_{2}$ levels in the systemic circulation, predisposing redox events more frequently in the lungs or (4) increased activity of GR in the peripheral blood of DEP-treated mice, compared with that in the other groups, may reflect an initial systemic response against the oxidative challenge.

AAs are capable of suppressing a variety of prooxidant enzymes involved in the production of ROS $[25,28]$ and can act directly as divalent metal ion chelators $[52,53]$, preventing the generation of superoxide anion $[19,52,54]$. Using the xanthine oxidase assay, Kubo et al. [52] demonstrated that at a concentration of $30 \mu \mathrm{L} / \mathrm{mL}$ AAs inhibit the formation of approximately $82 \%$ of superoxide anion. The mechanisms for this well-established effect remain unclear, but the degree of unsaturation of the $C_{15}$ alkyl side chain attached to benzene ring is closely related to the observed effects induced by AAs on cell structure and enzymes activities [52, 55, 56]. Taken together, AAs may contribute to the improvement of the oxidative status of compromised lung tissue by facilitating the recovery of GSH and other antioxidant levels. 


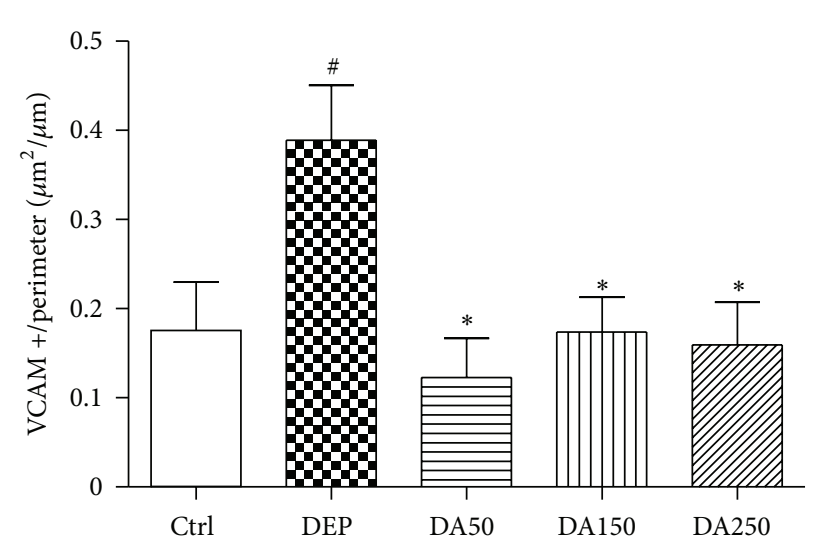

(a)

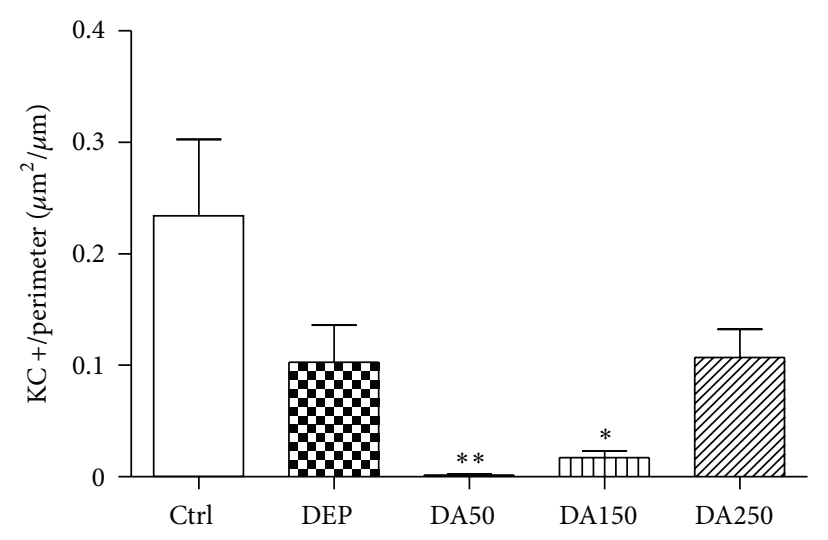

(b)

FIGURE 8: Vascular adhesion molecule (VCAM) (a) and KC (b) positive areas in peribronchiolar vessels. Values represent means \pm SEM. Ctrl: control; animals received an intranasal instillation of $10 \mu \mathrm{L}$ saline solution and were treated orally with $100 \mu \mathrm{L}$ of cashew nut oil (CNO). DEP: intranasal instillation of $50 \mu \mathrm{g} \mathrm{DEP} / 10 \mu \mathrm{L}$ of saline and treated orally with $100 \mu \mathrm{L}$ of CNO. DA50: intranasal instillation of $50 \mu \mathrm{g}$ DEP/10 $\mu \mathrm{L}$ of saline and treated orally with $50 \mathrm{mg} / \mathrm{kg}$ of AAs. DA150: intranasal instillation of $50 \mu \mathrm{g}$ DEP/10 $\mu \mathrm{L}$ of saline and treated orally with $150 \mathrm{mg} / \mathrm{kg}$ of AAs. DA250: intranasal instillation of $50 \mu \mathrm{g} \mathrm{DEP} / 10 \mu \mathrm{L}$ of saline and treated orally with $250 \mathrm{mg} / \mathrm{kg}$ of AAs. KC: keratinocyte chemoattractant. ${ }^{\#} P<0.05$ relative to Ctrl. ${ }^{*} P<0.05$ relative to DEP. ${ }^{* *} P<0.001$ relative to DEP.

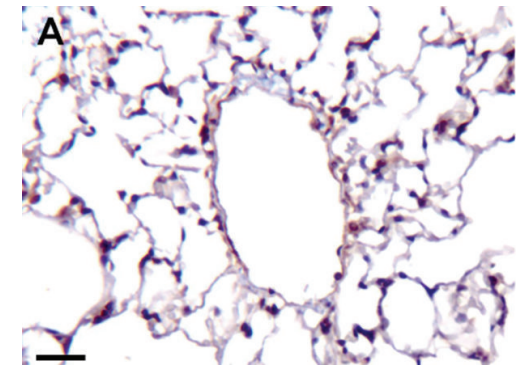

(a)

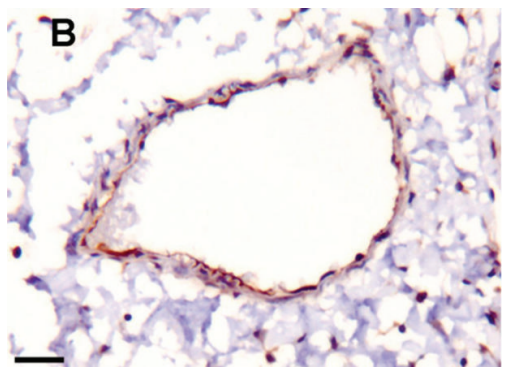

(b)

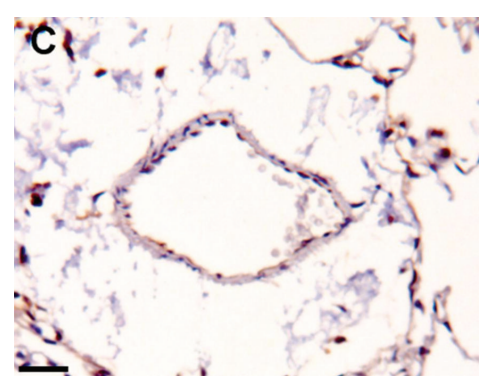

(c)

Figure 9: Photomicrographs depicting the increased vascular adhesion molecule (VCAM) area in peribronchiolar vessels of lung tissue. In the DEP-treated group (b) compared to both the Ctrl group (a) and to the group that received $50 \mathrm{mg} / \mathrm{kg}$ of anacardic acids (c) (Immunohistochemistry). Scale bars $=25 \mu \mathrm{m}$.

The effects of AAs described in this study are attributed to the mixture of AAs isoforms (anacardic acid-1, -2, -3, and -4) which were also used in the majority of in vivo studies $[23,32,52,54]$. Trevisan et al. [19] have previously described that anacardic acid-1 was the more potent antioxidant in the xanthine oxidase assay when compared to anacardic acid-2 and anacardic acid-3. The antioxidant capacity of anacardic acid-1 is explained by the three double bonds in the alkyl side chain, conferring greater antioxidant and enzyme inhibition capacity than the others acids that contain one-two double bonds in their molecules. Therefore, we speculate that the major antioxidant effects observed in this study may probably be assigned to anacardic acid-1.

In future studies, it will be interesting to analyze in vivo AA isotypes separately, since recent in vitro studies have shown different immunological properties on AAs compounds [57]. In our study, all administered doses of AAs were associated with increased antioxidant enzyme activity whereas only the $50 \mathrm{mg} / \mathrm{kg}$ dose of AAs reduced the increase in cytokine levels caused by DEP exposure. In fact at the 150 and $250 \mathrm{mg} / \mathrm{kg}$ doses, a significant increase in the concentration of IL-1 $\beta$ was observed. A possible reason for this is that the overall exposure to anacardic acid- 4 is increased above a threshold in the highest concentrations, whereby it could enhance the production of cytokines as described by Suo et al. [57] for IL-2, interferon- $\gamma$, IL-4, and IL-5.

A variety of studies have recognized AAs as potential therapeutic substances [23, 30, 52, 56, 58]. Morais et al. [23] described gastroprotective effects of AAs in a dose-related manner. Animals that received 10, 30, or $100 \mathrm{mg} / \mathrm{kg}$ of AAs orally have markedly reduced gastric damage induced by ethanol. A dose of $30 \mathrm{mg} / \mathrm{kg}$ of AAs was able to inhibit the depletion of GSH, catalase, superoxide dismutase, and nitrate/nitrite, reinforcing the antioxidant potential of anacardic acids.

Currently, there are no reports describing the effects of AAs on the modulation of lung inflammation. Sung et al. [30] demonstrated that AAs inhibit TNF- $\alpha$-activated NF- $\kappa$ B in human lung adenocarcinoma H1299 cells, revealing the potential chemotherapeutic effect of AAs for lung cancer. In 
our study, AAs did not affect the expression of TNF- $\alpha$ and $\mathrm{NF}-\kappa \mathrm{B}$ in cells in the lung parenchyma. It is possible that this model of subacute, low-DEP exposure was not appropriate for studying such mechanisms. Romieu et al. [2] proposed a hierarchical oxidative stress model that explains the dosedependent response to air pollutant exposure. This model explains that low levels of exposure lead to the formation of ROS, activating an antioxidant response. At higher levels of exposure, NF- $\kappa \mathrm{B}$ and AP-1 transcription is activated, increasing the expression of proinflammatory cytokines.

It is important to note the limitations of the present study. We have not determined the routes of absorption and the metabolism of AAs in mice, and this information is not available for humans. Kubo et al. [52] described several possibilities for these processes: AAs can be absorbed through the intestinal tract and delivered to regions where antioxidants are needed, absorbed as inactive forms, or excreted and not absorbed in human systems. Additionally, we did not study all the possible mechanisms by which AAs can influence the response of lung tissue against DEP.

\section{Conclusions}

In summary, the antioxidant and anti-inflammatory effects of AAs described in this study using a model of DEP-induced lung damage can be associated with the action of AAs in inhibiting the generation of $\operatorname{ROS}[19,25,52]$, which can directly or indirectly influence the inflammatory response of the lung.

Brazil is known for its biological megadiversity, with a large potential for the development of new therapeutic agents derived from native plants as the cashew tree. Much research is still needed in this area. In this study, we have demonstrated that AAs derived from cashew may have a potential role as a therapeutic substance in modulating pulmonary responses by improving antioxidant status. Based on this research, further studies are necessary to detail and describe the mechanisms of action for the observed responses induced by AAs in human health and particularly in the pulmonary system.

\section{Conflict of Interests}

The authors of this paper do not have a direct or indirect financial relation with any commercial mentioned. This work was supported exclusively by Grants from Brazilian Research Agencies from FAPESP and CNPq.

\section{Acknowledgments}

This work was supported by the Grants from Fundação de Amparo à Pesquisa do Estado de São Paulo (FAPESP, São Paulo, Brazil, 2007/05033-3) and Conselho Nacional de Desenvolvimento Científico e Tecnológico (CNPq, Brasília, Brazil).

\section{References}

[1] T. Wang, E. T. Chiang, L. Moreno-Vinasco et al., "Particulate matter disrupts human lung endothelial barrier integrity via
ROS- and p38 MAPK-dependent pathways," American Journal of Respiratory Cell and Molecular Biology, vol. 42, no. 4, pp. 442449, 2010.

[2] I. Romieu, F. Castro-Giner, N. Kunzli, and J. Sunyer, "Air pollution, oxidative stress and dietary supplementation: a review," European Respiratory Journal, vol. 31, no. 1, pp. 179-197, 2008.

[3] C. A. Pope III, R. T. Burnett, G. D. Thurston et al., "Cardiovascular mortality and long-term exposure to particulate air pollution: epidemiological evidence of general pathophysiological pathways of disease," Circulation, vol. 109, no. 1, pp. 71-77, 2004.

[4] SPTrans-São Paulo Transporte S.A, "Indicadores/Frota contratada," http://www.sptrans.com.br/indicadores/.

[5] A. Sydbom, A. Blomberg, S. Parnia, N. Stenfors, T. Sandström, and S. E. Dahlén, "Health effects of diesel exhaust emissions," European Respiratory Journal, vol. 17, no. 4, pp. 733-746, 2001.

[6] N. Stenfors, C. Nordenhäll, S. S. Salvi et al., "Different airway inflammatory responses in asthmatic and healthy humans exposed to diesel," European Respiratory Journal, vol. 23, no. 1, pp. 82-86, 2004.

[7] K. Yoshizaki, J. M. Brito, A. C. Toledo et al., "Subchronic effects of nasally instilled diesel exhaust particulates on the nasal and airway epithelia in mice," Inhalation Toxicology, vol. 22, no. 7, pp. 610-617, 2010.

[8] R. J. Pandya, G. Solomon, A. Kinner, and J. R. Balmes, "Diesel exhaust and asthma: hypotheses and molecular mechanisms of action," Environmental Health Perspectives, vol. 110, no. 1, pp. 103-112, 2002.

[9] D. Diaz-Sanchez and M. Riedl, "Diesel effects on human health: a question of stress?" American Journal of Physiology-Lung Cellular and Molecular Physiology, vol. 289, no. 5, pp. L722L723, 2005.

[10] M. Riedl and D. Diaz-Sanchez, "Biology of diesel exhaust effects on respiratory function," Journal of Allergy and Clinical Immunology, vol. 115, no. 2, pp. 221-228, 2005.

[11] J. A. Nightingale, R. Maggs, P. Cullinan et al., "Airway inflammation after controlled exposure to diesel exhaust particulates," American Journal of Respiratory and Critical Care Medicine, vol. 162, no. 1, pp. 161-166, 2000.

[12] B. L. Halvorsen, K. Holte, M. C. W. Myhrstad et al., "A systematic screening of total antioxidants in dietary plants," Journal of Nutrition, vol. 132, no. 3, pp. 461-471, 2002.

[13] N. M. Elsayed, "Antioxidant mobilization in response to oxidative stress: a dynamic environmental-nutritional interaction," Nutrition, vol. 17, no. 10, pp. 828-834, 2001.

[14] H. Takizawa, "Diesel exhaust particles and their effect on induced cytokine expression in human bronchial epithelial cells," Current Opinion in Allergy and Clinical Immunology, vol. 4, no. 5, pp. 355-359, 2004.

[15] F. J. Kelly, "Vitamins and respiratory disease: antioxidant micronutrients in pulmonary health and disease," Proceedings of the Nutrition Society, vol. 64, no. 4, pp. 510-526, 2005.

[16] I. S. Mudway, N. Stenfors, S. T. Duggan et al., "An in vitro and in vivo investigation of the effects of diesel exhaust on human airway lining fluid antioxidants," Archives of Biochemistry and Biophysics, vol. 423, no. 1, pp. 200-212, 2004.

[17] N. H. Al-Humadi, P. D. Siegel, D. M. Lewis et al., "Alteration of intracellular cysteine and glutathione levels in alveolar macrophages and lymphocytes by diesel exhaust particle exposure," Environmental Health Perspectives, vol. 110, no. 4, pp. 349353, 2002. 
[18] A. Scalbert, C. Manach, C. Morand, C. Rémésy, and L. Jiménez, "Dietary polyphenols and the prevention of diseases," Critical Reviews in Food Science and Nutrition, vol. 45, no. 4, pp. 287306, 2005.

[19] M. T. S. Trevisan, B. Pfundstein, R. Haubner et al., "Characterization of alkyl phenols in cashew (Anacardium occidentale) products and assay of their antioxidant capacity," Food and Chemical Toxicology, vol. 44, no. 2, pp. 188-197, 2006.

[20] J. Kubo, J. R. Lee, and I. Kubo, "Anti-Helicobacter pylori agents from the cashew apple," Journal of Agricultural and Food Chemistry, vol. 47, no. 2, pp. 533-537, 1999.

[21] I. Kubo, K. I. Nihei, and K. Tsujimoto, "Antibacterial action of anacardic acids against Methicillin Resistant Staphylococcus aureus (MRSA)," Journal of Agricultural and Food Chemistry, vol. 51, no. 26, pp. 7624-7628, 2003.

[22] H. Muroi and I. Kubo, "Antibacterial activity of anacardic acid and totarol, alone and in combination with methicillin, against methicillinresistant Staphylococcus aureus," Journal of Applied Bacteriology, vol. 80, no. 4, pp. 387-394, 1996.

[23] T. C. Morais, N. B. Pinto, K. M. M. B. Carvalho et al., "Protective effect of anacardic acids from cashew (Anacardium occidentale) on ethanol-induced gastric damage in mice," ChemicoBiological Interactions, vol. 183, no. 1, pp. 264-269, 2010.

[24] S. V. Shobha, C. S. Ramadoss, and B. Ravindranath, "Inhibition of soybean lipoxygenase-1 by anacardic acids, cardols, and cardanols," Journal of Natural Products, vol. 57, no. 12, pp. 17551757, 1994.

[25] T. J. Ha and I. Kubo, "Lipoxygenase inhibitory activity of anacardic acids," Journal of Agricultural and Food Chemistry, vol. 53, no. 11, pp. 4350-4354, 2005.

[26] R. Grazzini, D. Hesk, E. Heininger et al., "Inhibition of lipoxygenase and prostaglandin endoperoxide synthase by anacardic acids," Biochemical and Biophysical Research Communications, vol. 176, no. 2, pp. 775-780, 1991.

[27] R. Paramashivappa, P. Phani Kumar, P. V. Subba Rao, and A. Srinivasa Rao, "Design, synthesis and biological evaluation of benzimidazole/benzothiazole and benzoxazole derivatives as cyclooxygenase inhibitors," Bioorganic and Medicinal Chemistry Letters, vol. 13, no. 4, pp. 657-660, 2003.

[28] Y. Sun, X. Jiang, S. Chen, and B. D. Price, "Inhibition of histone acetyltransferase activity by anacardic acid sensitizes tumor cells to ionizing radiation," Federation of European Biochemical Societies Letters, vol. 580, no. 18, pp. 4353-4356, 2006.

[29] F. J. Dekker and H. J. Haisma, "Histone acetyl transferases as emerging drug targets," Drug Discovery Today, vol. 14, no. 1920, pp. 942-948, 2009.

[30] B. Sung, M. K. Pandey, K. S. Ann et al., "Anacardic acid (6nonadecyl salicylic acid), an inhibitor of histone acetyltransferase, suppresses expression of nuclear factor- $\kappa$ B-regulated gene products involved in cell survival, proliferation, invasion, and inflammation through inhibition of the inhibitory subunit of nuclear factor-KBa kinase, leading to potentiation of apoptosis," Blood, vol. 111, no. 10, pp. 4880-4891, 2008.

[31] Y. Wu, L. He . Zhang et al., "Anacardic acid (6-pentadecyl salicylic acid) inhibits tumor angiogenesis by targeting Src/FAK/ Rho GTPases signaling pathway," Journal of Pharmacology and Experimental Therapeutics, vol. 339, no. 2, pp. 403-411, 2011.

[32] M. Hemshekhar, M. Sebastin Santhosh, K. Kemparaju, and K. S. Girish, "Emerging roles of anacardic acid and its derivatives: a pharmacological overview," Basic \& Clinical Pharmacology \& Toxicology, vol. 110, no. 2, pp. 122-132, 2012.
[33] A. L. N. Carvalho, R. Annoni, P. R. P. Silva et al., "Acute, subacute toxicity and mutagenic effects of anacardic acids from cashew (Anacardium occidentale Linn.) in mice," Journal of Ethnopharmacology, vol. 135, no. 3, pp. 730-736, 2011.

[34] R. Paramashivappa, P. Phani Kumar, P. J. Vithayathil, and A. Srinivasa Rao, "Novel method for isolation of major phenolic constituents from cashew (Anacardium occidentale L.) Nut shell liquid," Journal of Agricultural and Food Chemistry, vol. 49, no. 5, pp. 2548-2551, 2001.

[35] D. Laks, R. C. de Oliveira, P. A. de André et al., "Composition of diesel particles influences acute pulmonary toxicity: an experimental study in MICE," Inhalation Toxicology, vol. 20, no. 11, pp. 1037-1042, 2008.

[36] T. Vijayalakshmi, V. Muthulakshmi, and P. Sachdanandam, "Effect of the milk extract of Semecarpus anacardium nut on adjuvant arthritis-a dose-dependent study in Wistar albino rats," General Pharmacology, vol. 27, no. 7, pp. 1223-1226, 1996.

[37] O. A. Olajide, M. A. Aderogba, A. D. A. Adedapo, and J. M. Makinde, "Effects of Anacardium occidentale stem bark extract on in vivo inflammatory models," Journal of Ethnopharmacology, vol. 95, no. 2-3, pp. 139-142, 2004.

[38] V. R. Ramprasath, P. Shanthi, and P. Sachdanandam, "Antiinflammatory effect of Semecarpus anacardium Linn. Nut extract in acute and chronic inflammatory conditions," Biological and Pharmaceutical Bulletin, vol. 27, no. 12, pp. 2028-2031, 2004.

[39] N. A. Konan and E. M. Bacchi, "Antiulcerogenic effect and acute toxicity of a hydroethanolic extract from the cashew (Anacardium occidentale L.) leaves," Journal of Ethnopharmacology, vol. 112, no. 2, pp. 237-242, 2007.

[40] L. Flohé and W. A. Günzler, "Assays of glutathione peroxidase," Methods in Enzymology, vol. 105, no. 1, pp. 114-121, 1984.

[41] I. Carlberg and B. Mannervik, "Purification and characterization of the flavoenzyme glutathione reductase from rat liver," Journal of Biological Chemistry, vol. 250, no. 14, pp. 5475-5480, 1975.

[42] W. H. Habig, M. J. Pabst, and W. B. Jakoby, "Glutathione S-transferases. The first enzymatic step in mercapturic acid formation," Journal of Biological Chemistry, vol. 249, no. 22, pp. 7130-7139, 1974.

[43] H. Aebi, "Catalase in vitro," Methods in Enzymology, vol. 105, pp. 121-126, 1984.

[44] T. Lanças, D. I. Kasahara, C. M. Prado, I. F. L. C. Tibério, M. A. Martins, and M. Dolhnikoff, "Comparison of early and late responses to antigen of sensitized guinea pig parenchymal lung strips," Journal of Applied Physiology, vol. 100, no. 5, pp. 16101616, 2006.

[45] M. Dolhnikoff, L. F. F. da Silva, B. B. de Araujo et al., "The outer wall of small airways is a major site of remodeling in fatal asthma," Journal of Allergy and Clinical Immunology, vol. 123, no. 5, pp. 1090.e1-1097.e1, 2009.

[46] CETESB (Companhia de Tecnologia de Saneamento Ambiental), "Relatório de qualidade do ar do Estado de São PauloSérie Relatório-Secretaria do Estado do Meio Ambiente," CETESB, São Paulo, Brazil, 2008, http://www.cetesb.sp.gov .br/ar/qualidade-do-ar/31-publicacoes-e-relatorios.

[47] N. Ballatori, S. M. Krance, S. Notenboom, S. Shi, K. Tieu, and C. L. Hammond, "Glutathione dysregulation and the etiology and progression of human diseases," Biological Chemistry, vol. 390, no. 3, pp. 191-214, 2009. 
[48] L. D. Deleve and N. Kaplowitz, "Importance and regulation of hepatic glutathione," Seminars in Liver Disease, vol. 10, no. 4, pp. 251-266, 1990.

[49] J. J. Haddad and H. L. Harb, "L- $\gamma$-glutamyl-L-cysteinyl-glycine (glutathione; GSH) and GSH-related enzymes in the regulation of pro- and anti-inflammatory cytokines: a signaling transcriptional scenario for redox(y) immunologic sensor(s)?" Molecular Immunology, vol. 42, no. 9, pp. 987-1014, 2005.

[50] D. F. A. R. Dourado, P. A. Fernandes, B. Mannervik, and M. J. Ramos, "Glutathione transferase: new model for glutathione activation," Chemistry, vol. 14, no. 31, pp. 9591-9598, 2008.

[51] R. Banerjee, Redox Biochemistry, John Wiley \& Sons, Hoboken, NJ, USA, 2008.

[52] I. Kubo, N. Masuoka, T. J. Ha, and K. Tsujimoto, "Antioxidant activity of anacardic acids," Food Chemistry, vol. 99, no. 3, pp. 555-562, 2006.

[53] S. J. Correia, J. P. David, and J. M. David, "Metabólitos secundários de espécies de Anacardiaceae," Química Nova, vol. 29, no. 6, pp. 1287-1300, 2006.

[54] N. Masuoka and I. Kubo, "Characterization of xanthine oxidase inhibition by anacardic acids," Biochimica et Biophysica Acta, vol. 1688, no. 3, pp. 245-249, 2004.

[55] F. H. A. Rodrigues, J. P. A. Feitosa, N. M. P. S. Ricardo, F. C. F. De França, and J. O. B. Carioca, "Antioxidant activity of Cashew Nut Shell Liquid (CNSL) derivatives on the thermal oxidation of synthetic cis-1,4-polyisoprene," Journal of the Brazilian Chemical Society, vol. 17, no. 2, pp. 265-271, 2006.

[56] K. Tsujimoto, A. Hayashi, T. J. Ha, and I. Kubo, "Anacardic acids and ferric ion chelation," Zeitschrift fur Naturforschung C, vol. 62, no. 9-10, pp. 710-716, 2007.

[57] M. Suo, H. Isao, Y. Ishida et al., "Phenolic lipid ingredients from cashew nuts," Journal of Natural Medicines, vol. 66, no. 1, pp. 133-139, 2012.

[58] I. Kubo, M. Ochi, P. C. Vieira, and S. Komatsu, "Antitumor agents from the cashew (Anacardium occidentale) apple juice," Journal of Agricultural and Food Chemistry, vol. 41, no. 6, pp. 1112-1115, 1993. 


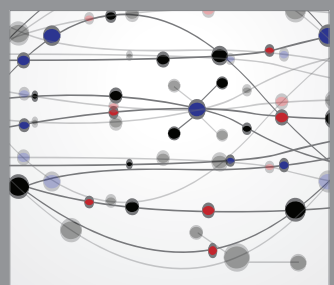

The Scientific World Journal
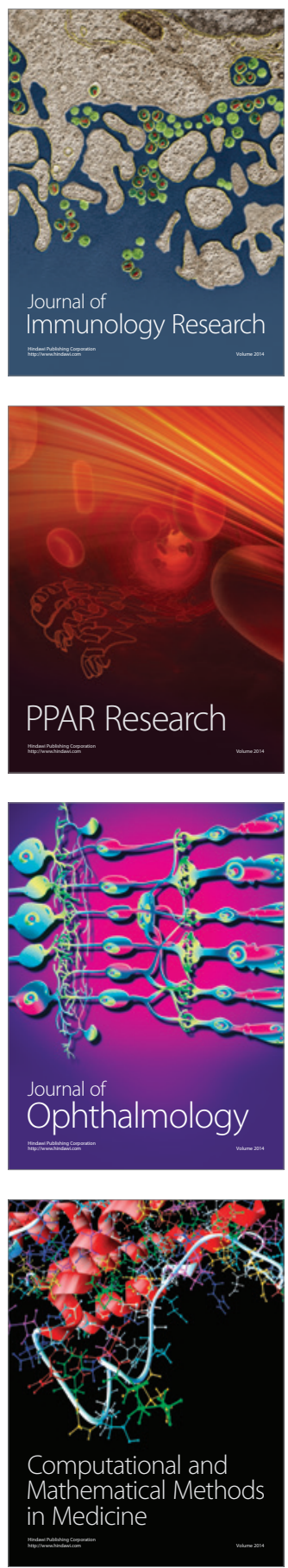

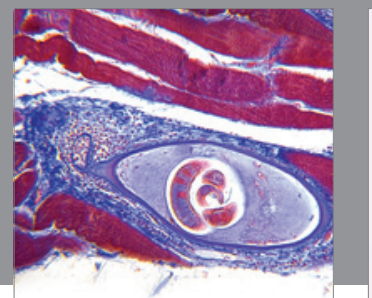

Gastroenterology

Research and Practice
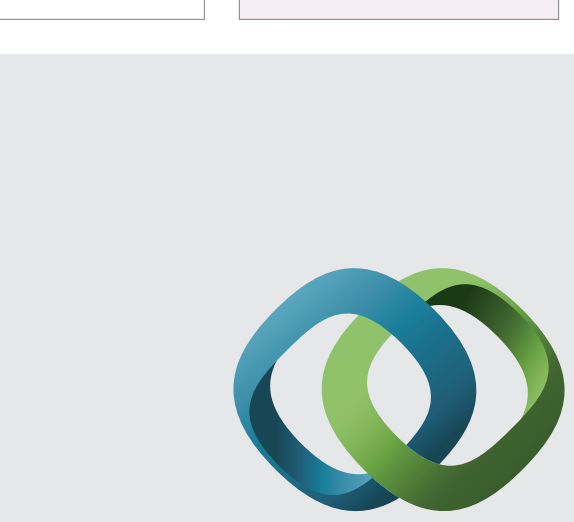

\section{Hindawi}

Submit your manuscripts at

http://www.hindawi.com
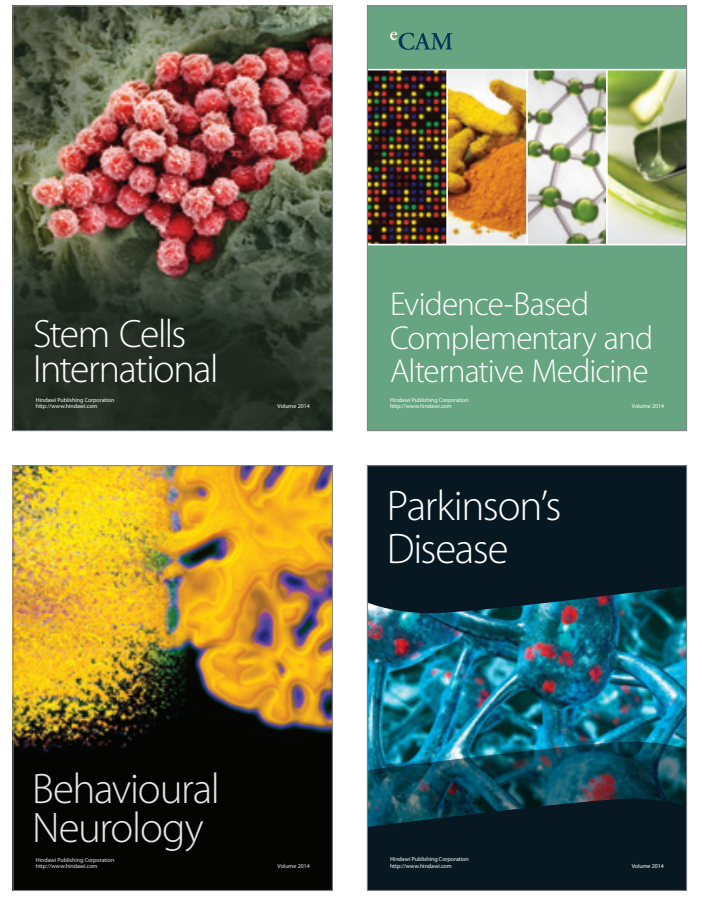
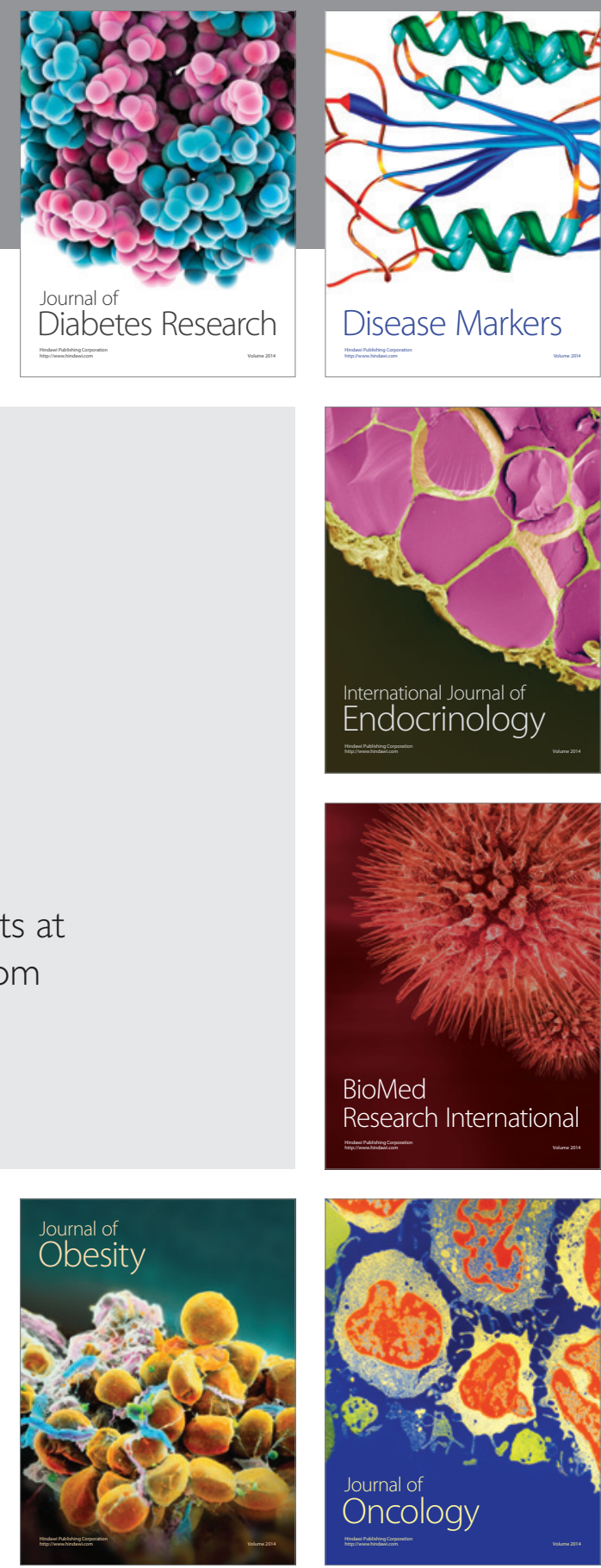

Disease Markers
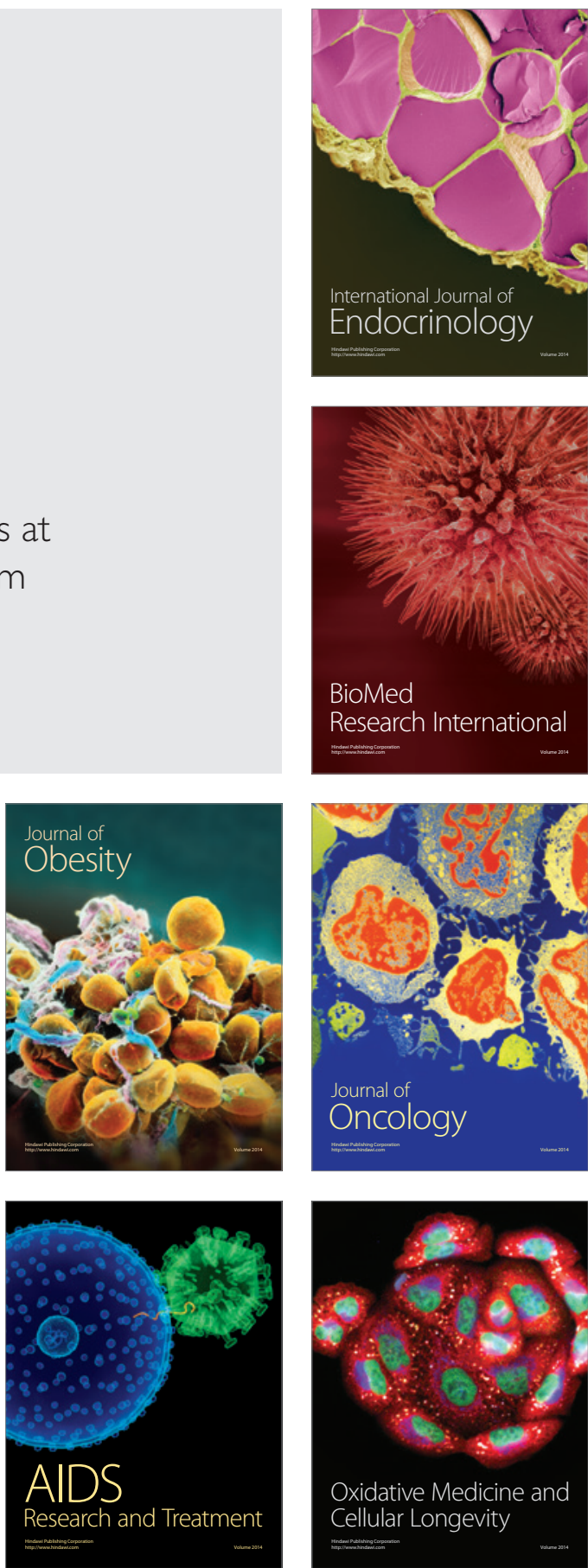